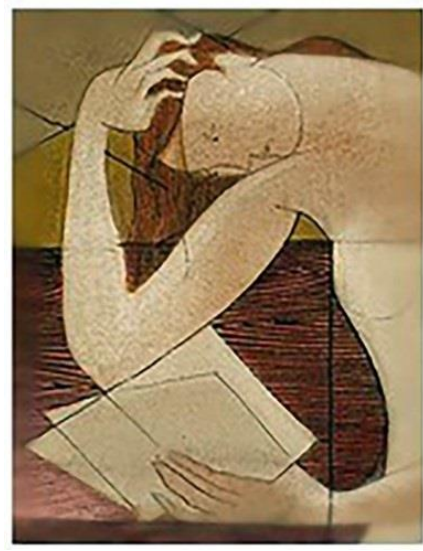

Nau Literária

crítica e teoria da literatura em língua portuguesa

PPG-LET UFRGS

ISSN 1981-4526

https://seer.ufrgs.br/NauLiteraria

V. 17, n.1 - 2021

Dossiê Clarice Lispector: Iluminações para o tempo presente

\title{
Ser galinha. Ou: o estado de galinha, em Clarice Lispector Chicken being. Or chicken state, in Clarice Lispector
}

\section{Davi Andrade Pimentel ${ }^{1}$}

Resumo: Este artigo propõe apresentar a relevância da concepção de estado de galinha, formulada por nós, na construção textual da obra de Clarice Lispector. Visto, sobretudo, da perspectiva do alheamento do real, o estado de galinha está presente tanto nos textos em que o animal galinha é retratado, quanto nos textos em que os personagens humanos, em sua maioria femininos, optam por esse alheamento do mundo real, próprio do animal galinha, como atestam muitos dos narradores claricianos. Desse modo, podemos concluir que o estado de galinha se inscreve na obra de Lispector por duas vias: enquanto tema, como observamos, por exemplo, no conto "Amor", presente em Laços de família; e enquanto efeito criador, como constatamos, por exemplo, na estrutura em formato de ovo do conto "O ovo e a galinha", presente em A legião estrangeira. Dada a devida importância do tema para as questões do nosso presente, este artigo será dividido em dois momentos: no primeiro, pretendemos definir o conceito de estado de galinha e a sua reverberação textual a partir das ações dos personagens humanos; e, no segundo, discutiremos a diferença supostamente existente entre o olhar do animal e o olhar humano.

Palavras-chave: Clarice Lispector; estado de galinha; galinha; alheamento do real.

Abstract: This article aims to present the relevance of the chicken state, a conception we formulated, in the textual construction of Clarice Lispector's work. Considered, above all, from the perspective of the detachment from reality, the chicken state is present both in the texts in which the animal is portrayed and in the texts in which human characters, most of them being the female ones, choose to be detached from this real world, a characteristic of the animal, what is indicated by many of Clarice's narrators. Thus, it is possible to come to the conclusion that the chicken state is present in Lispector's work in two different ways: as the theme, as we observe, for instance, in the short story "Love", part of the work Family Ties; and as the creator, as we can see, for example, in the egg structure shape of the short story The Egg and the Chicken, of The Foreign Legion. Given the importance of the theme to our present issues, this article will be divided in two moments: in the first, we intend to define the chicken state conception and its textual reverberation from the actions of the human characters; and, in the second, we will discuss about the supposedly existing difference between the animal's and the human's views.

Keywords: Clarice Lispector; chicken state; chicken; detachment from the real.

Encostando a testa na vidraça brilhante e fria olhava para o quintal do vizinho, para o grande mundo das galinhas-que-nãosabiam-que-iam-morrer. E podia sentir como se estivesse bem

\footnotetext{
1 Pós-doutorando sênior com bolsa Faperj, atuando no Departamento de Ciência da Literatura da Universidade Federal do Rio de Janeiro. Pós-doutor com bolsa Faperj, atuando no Departamento de Letras Modernas do Instituto de Letras da Universidade Federal Fluminense. Trabalha com a tradução para o português de textos do escritor francês Maurice Blanchot. Doutor em Literatura Comparada pela Universidade Federal Fluminense. Mestre em Literatura Brasileira pela Universidade Federal do Ceará. Graduado em Letras-Literaturas pela Universidade Federal do Ceará.
} 


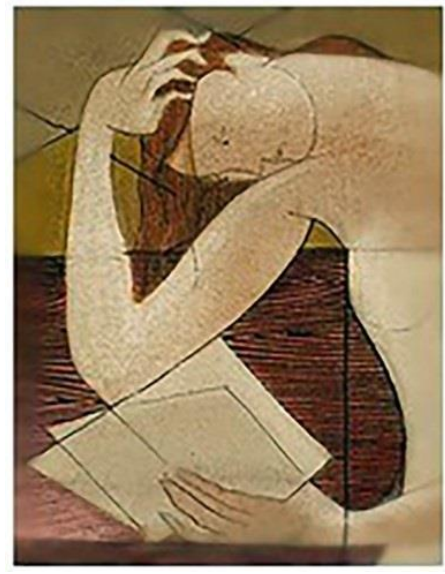

Nau Literária

crítica e teoria da literatura em língua portuguesa

PPG-LET UFRGS

ISSN 1981-4526

\author{
https://seer.ufrgs.br/NauLiteraria \\ V. 17, n.1 - 2021
}

Dossiê Clarice Lispector: Iluminações para o tempo presente

próxima de seu nariz a terra quente, socada, tão cheirosa e seca, onde bem sabia, bem sabia uma ou outra minhoca se espreguiçava antes de ser comida pela galinha que as pessoas iam comer.

(Perto do coração selvagem. Clarice Lispector)

\title{
Sentir e não pensar: ser galinha
}

Sobre galinhas e suas relações com elas próprias, com as pessoas e sobretudo com sua gravidez de ovo, escrevi a vida toda, e falar sobre macacos também já falei.

("Bichos (I)". Clarice Lispector)

Na obra clariciana, dentre os seus vários temas e personagens, um, a meu ver, excede a sua escrita: a galinha. ${ }^{2}$ Animal (não) domesticável cuja presença se inscreve desde as primeiras linhas de Perto do coração selvagem, romance inaugural de Clarice Lispector, até as linhas finais de seu último romance, A hora da estrela, quando Macabéa, após ser atropelada por um Mercedes amarelo, tal como atingida por uma estrela cadente, é comparada pelo narrador Rodrigo S. M. a uma galinha: "Ela sofria? Acho que sim. Como uma galinha de pescoço mal cortado que corre espavorida pingando sangue. Só que a galinha foge - como se foge da dor - em cacarejos apavorados. E Macabéa lutava muda." (LISPECTOR, 2020 b, p. 73). Há, em especial, um legítimo drama de escritura em torno do ser galinha em Lispector: um animal descrito por vários narradores como absurdamente tolo e comum, alheio a tudo o que o cerca, preocupado apenas em

\footnotetext{
${ }^{2}$ Em Clarice Lispector com a ponta dos dedos, Vilma Arêas destaca que a grande (não) heroína da obra de Lispector é a galinha. No capítulo "Children's Corner", Arêas, ao assinalar a problemática da construção do herói em termos míticos e ideais em nossa modernidade, pontua que, ao fracasso e ao inacabamento de seus heróis sempre em compasso de perda e frustração, os textos de Lispector respondem com uma incursão violenta na banalidade do cotidiano, não dando margem nem para uma simples estranheza, nem para uma simples ironia ou sarcasmo, mas sim convergindo para uma pura banalidade oca que toma forma na figura da galinha em seus textos: "O problema da construção do herói, recorrente em grande parte dos fíccionistas modernos, como sabemos, é tratado intuitivamente por ela, mas de forma insistente. Aos poucos toma corpo de maneira talvez brutal, pois ao fracasso da unidade e à impossibilidade de reintegração é dada uma imagem ímpar e arrasadora pela banalidade. [...] Trata-se, em Clarice, da galinha. Bicho caseiro, oco e sem grandeza, embora abrigue em si o incompreensível e perfeito ovo, a galinha é personagem à parte nos mais diversos textos de nossa autora." (ARÊAS, 2005, p. 126-7).
} 


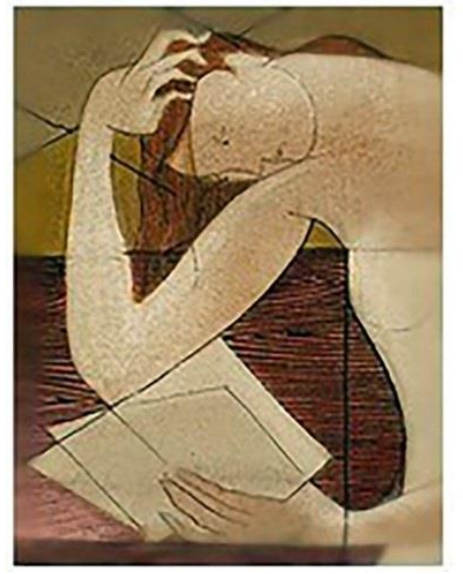

Nau Literária

crítica e teoria da literatura em língua portuguesa

PPG-LET UFRGS

ISSN 1981-4526

\author{
https://seer.ufrgs.br/NauLiteraria \\ V. 17, n.1 - 2021
}

Dossiê Clarice Lispector: Iluminações para o tempo presente

sobreviver, jamais em viver; embora este mesmo animal seja dotado de uma individualidade tão inapreensível e tão fascinante que faz com que esses narradores "percam tempo" na observação esvaziada de sua vida galinácea vazia: "A galinha é sempre a tragédia mais moderna. Está sempre inutilmente a par. [...] Mas para a galinha não há jeito: está na sua condição não servir a si própria.” (LISPECTOR, 2016, p. 307).

Nesse curto fragmento do conto "O ovo e a galinha", destaquemos dois instantes de escritura que, como em outros momentos do conto, tendem a fazer oscilar a sua estrutura narrativa, a ponto de conduzi-la a um caminho de quase, ou de muita, ininteligibilidade interpretativa: a concepção de a galinha ser uma tragédia moderna e a inutilidade da galinha para si própria. De antemão, o conto "O ovo e a galinha" é um legítimo nó interpretativo, pouco deslindável, e, talvez, que não se queira deslindável, pois o jorro ininterrupto de frases de sua narradora, ao limite da verborragia excessiva, quebra não apenas as sequências de suas frases, como sobretudo a sua lógica. Ou seja, não há uma construção do pensamento sobre o ovo e, logo depois, sobre a galinha, como o esperado, mas uma interrupção do pensamento, que faz do ovo e da galinha termos que escapam, que se subtraem, ao sistema linguístico conhecido e utilizado corriqueiramente por seu leitor: "E o ovo fica inteiramente protegido por tantas palavras." (LISPECTOR, 2016, p. 313). Por essa razão, o ovo e a galinha, neste conto, são substantivos sem significado, uma vez que estão profundamente submersos em uma operação caudalosa de significações promovida por sua narradora que acaba por fazer fracassar as definições a eles atribuídas - a concentração de múltiplos atributos resulta em um esvaziamento de atributo:

E a galinha? O ovo é o grande sacrifício da galinha. O ovo é a cruz que a galinha carrega na vida. O ovo é o sonho inatingível da galinha. A galinha ama o ovo. Ela não sabe que existe o ovo. Se soubesse que tem em si mesma um ovo, ela se salvaria? Se soubesse que tem em si mesma o ovo, perderia o estado de galinha. Ser uma galinha é a sobrevivência da galinha. Sobreviver é a salvação. Pois parece que viver não existe. Viver leva à morte. Então o que a galinha faz é estar permanentemente sobrevivendo. Sobreviver chama-se manter luta contra a vida que é mortal. Ser uma galinha é isso. A galinha tem o ar constrangido. 


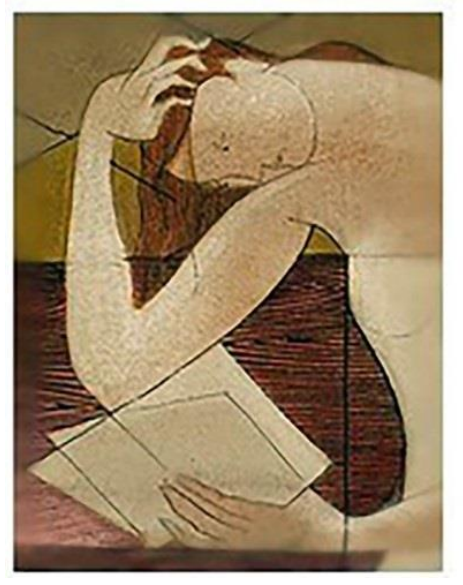

Nau Literária

crítica e teoria da literatura em língua portuguesa

PPG-LET UFRGS ISSN 1981-4526

https://seer.ufrgs.br/NauLiteraria
V. 17, n.1 - 2021

Dossiê Clarice Lispector: Iluminações para o tempo presente

(LISPECTOR, 2016, p. 306, grifos meus)

Desde o seu início em ovo-verbo, "- A você dedico o começo. A você dedico a primeira vez." (LISPECTOR, 2016, p. 303), que retoma e ressignifica, modificando-os, os primeiros versículos do Evangelho segundo João: "No princípio era o verbo, e o verbo estava com Deus, e Deus era o verbo.” (BÍBLIA, João, 1:1-2), sendo por essa razão que de "ovo a ovo chega-se a Deus, que é invisível a olho nu." (LISPECTOR, 2016, p. 304), a escrita do conto "O ovo e a galinha" se permite, ou melhor, se autoriza, a partir da divindade inapreensível do ovo, a executar constantes torções em suas frases, retirandolhes, a curto prazo, todo e qualquer investimento significativo e, com isso, deslocando os referentes usualmente manejados pelo leitor na compreensão dos significantes ovo e galinha - nem sempre o ovo e a galinha claricianos são os ovos e as galinhas de nosso cotidiano, eles costumam ser outra coisa: "O ovo é uma coisa suspensa. [...] - Eu te amo, ovo. Eu te amo como uma coisa nem sequer sabe que ama outra coisa." (LISPECTOR, 2016, p. 304, grifos meus). Sendo coisa, o ovo é, ao mesmo tempo, algo da ordem da imaterialidade e da materialidade ou, se preferirmos, algo tão abstrato quanto real, suspendendo, desse modo, a linha limitadora do conceito e de sua significação: "Dessa forma, a galinha e o seu ovo interno encenam o duplo agir, o entender e o não entender, ou seja, o que é e o que não é.” (GOTLIB, 2013, p. 439). Ser coisa é tudo o que existe e não existe, a coisa excede. E por exceder, a operação atributiva exaustiva da narradora fracassa, é em vão que ela procura definir o indefinível: "o ovo é" resta sem traço, ou melhor, seus traços são e estão constantemente apagados, posto que coisa, logo, ser "uma galinha é isso", algo também da ordem do inapreensível, que resta sem predicado, uma vez que não há galinha sem ovo: "Ovo é coisa que precisa tomar cuidado. Por isso a galinha é o disfarce do ovo. Para que o ovo atravesse os tempos a galinha existe." (LISPECTOR, 2016, p. 305, grifos meus). Contudo, há aqui um mal-entendido. 


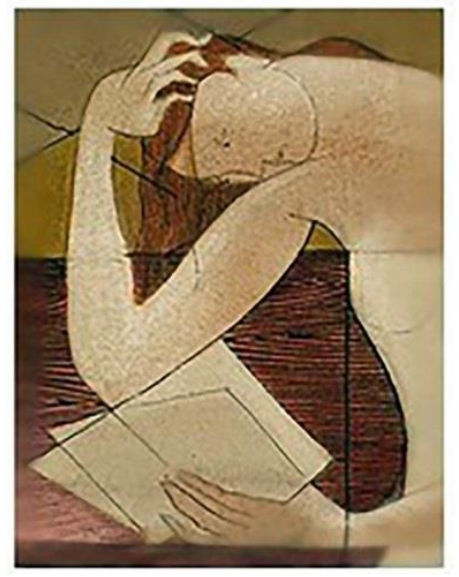

Nau Literária

crítica e teoria da literatura em língua portuguesa

PPG-LET UFRGS

ISSN 1981-4526

\author{
https://seer.ufrgs.br/NauLiteraria \\ V. 17, n.1 - 2021
}

Dossiê Clarice Lispector: Iluminações para o tempo presente

Um mal-entendido de perspectiva, claro. Tão alheia ao que diz quanto, acreditase, a galinha ao que a cerca, a narradora do conto pouco ou nada se demora em um esquadrinhamento mais aprofundado sobre o que declama - aludo ao verbo declamar, pois, a meu ver, a narradora age como um bom ator que decorou bem o seu texto, mas que não o compreendeu: "Falai muito, é uma das instruções, estou tão cansada." (LISPECTOR, 2016, p. 313, grifos meus). Alheamento que não encontramos, por exemplo, no conto "A legião estrangeira", no qual cada passo de escrita é substância de reflexão para a sua narradora: do aparecimento de um pintinho à recordação da morte do antigo pinto por Ofélia, a criança estrangeira que mata por amor, ou desamor. Por ser toda sentimentos para com o ovo, e por não o submeter à análise de seu pensamento - dizer algo não significa refletir sobre algo -, a narradora de "O ovo e a galinha" se aproxima da existência da galinha, um animal que, segundo os narradores claricianos, apenas sente, mas não pensa: "Por devoção ao ovo, eu o esqueci. Meu necessário esquecimento. Meu interesseiro esquecimento. Pois o ovo é um esquivo. Diante de minha adoração possessiva ele poderia retrair-se e nunca mais voltar." (LISPECTOR, 2016, p. 313, grifos meus). Na crônica "Um pintinho", de A descoberta do mundo, a escrita clariciana reitera uma vez mais a ideia da galinha, ou do galo, ser um animal de sensações, jamais de pensamentos: "Um de meus filhos comprou um pintinho amarelo. Que pena que dá. Sente-se nele a falta da mãe. O susto de ter nascido do nada. E nenhum pensamento, apenas sensações." (LISPECTOR, 2020, p. 89). Nessa breve crônica, como veremos a seguir, pode-se obter a resposta para o ato assassínio da menina Ofélia.

Ao aproximar-se da existência da galinha, alheada de tal forma de seu mundo em favor da legítima adoração à coisa-ovo, a narradora de “O ovo e a galinha” faz da estrutura de seu texto uma estrutura discursiva em formato de ovo, um ovo-conto, um ovo-discurso, um ovo-palavra:

Os ovos estalam na frigideira, e mergulhada no sonho preparo o café da manhã. Sem nenhum senso da realidade, grito pelas crianças que brotam de várias camas, arrastam 


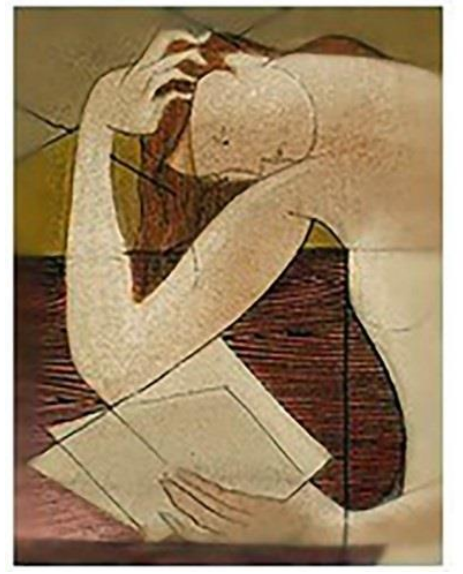

Nau Literária

crítica e teoria da literatura em língua portuguesa

PPG-LET UFRGS

ISSN 1981-4526

\author{
https://seer.ufrgs.br/NauLiteraria \\ V. 17, n.1 - 2021
}

Dossiê Clarice Lispector: Iluminações para o tempo presente

cadeiras e comem, e o trabalho do dia amanhecido começa, gritado e rido e comido, clara e gema, alegria entre brigas, dia que é o nosso sal e nós somos o sal do dia, viver é extremamente tolerável, viver ocupa e distrai, viver faz rir.

(LISPECTOR, 2016, p. 310-1, grifos meus)

Em momento anterior do conto, diz a narradora sobre a galinha: "- A galinha vive como em sonho. Não tem senso da realidade. Todo o susto da galinha é porque estão sempre interrompendo o seu devaneio. A galinha é um grande sono.” (LISPECTOR, 2016, p. 306, grifos meus). Em um cotejo desses dois instantes de escritura, constatamos que tanto a galinha quanto a narradora estão fora da realidade e vivem como em sonho, alheias ao tempo e ao espaço real que as sitiam: o alhear-se, ou seja, o viver em sonho é um modo de sobrevivência, um estar no mundo fora do mundo. Nesse sentido, em Lispector, ser galinha é um estado, e não apenas um significante que se refere a um animal da classe dos galináceos: "Ser uma galinha é a sobrevivência da galinha. Sobreviver é a salvação. Pois parece que viver não existe. Viver leva à morte.” (LISPECTOR, 2016, p. 306). E sendo um estado, ser galinha movimenta duas ações discursivas nos textos claricianos: uma primeira ação, a criadora, como em "O ovo e a galinha", na qual a narradora, em estado de galinha, alheada do mundo, dá à luz o seu ovo-escritura, o seu texto-ovo-incógnita, pois coisa. E uma segunda ação, de covardia, esta por parte de seus personagens, em sua maioria femininos, que, ou protegidos por seu mundo perfeito do casamento ou por uma ideia de mundo perfeito ou sem coragem para enfrentarem a sujidade do real ou inaptos aos sentimentos reais que por vezes machucam, se acomodam a um estado de galinha, alheados da realidade que os oprimiria ou mataria caso rompessem com sua idealização de mundo, de casamento e de relação com o outro. $\mathrm{Ou}$ seja, a idealização significa também um estado de sono ou de perda do senso da realidade em Lispector. Mas isso não nos leva a afirmar que esse estado de galinha seja permanente, pelo contrário, muitos personagens claricianos abandonam esse estado quando se deparam com algo que os obriga a ver, a sentir e a desejar toda a aspereza do mundo real, 

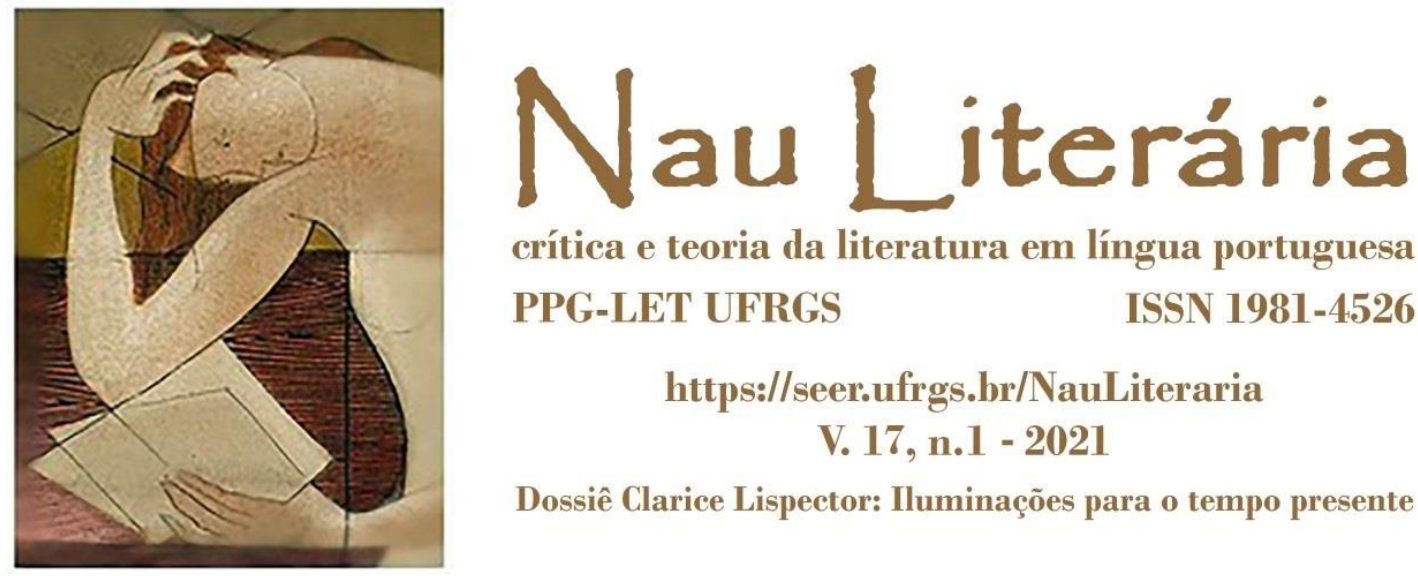

crítica e teoria da literatura em língua portuguesa

PPG-LET UFRGS

ISSN 1981-4526

$$
\begin{gathered}
\text { https://seer.ufrgs.br/NauLiteraria } \\
\text { V. 17, n.1 - } 2021
\end{gathered}
$$

Dossiê Clarice Lispector: Iluminações para o tempo presente

embora outros não, como, por exemplo, Ana, a protagonista do conto “Amor”, de Laços de família.

Como um grande e belo embrulho, Ana enfeitava o seu mundo particular, leia-se, casamento, família e casa, dava-lhe laços cada vez mais perfeitos com o zelo de quem praticava todos os dia, dispondo do tempo como certa de que "a vida podia ser feita pela mão do homem.” (LISPECTOR, 2020 a, p. 18). A personagem forjava, assim, o seu mundo decorativo, alheado da desordem do mundo comum, sujo, e que era sobretudo contaminado pela felicidade. Segundo Ana, a felicidade é um estado que antecipava a vinda do caos derivado da infelicidade que lhe é inerente. Pois como se pode viver infeliz? Então, é preciso manter a felicidade à distância - o estado de felicidade não se harmoniza com o estado de galinha: "Dela [de sua juventude] havia aos poucos emergido para descobrir que também sem a felicidade se vivia [...]. Criara em troca algo enfim compreensível, uma vida de adulto. Assim ela o quisera e escolhera." (LISPECTOR, 2020 a, p. 18). Para Ana, é preferível ter a verdade, ou a suposta ideia que se tem dela, e sua pretensa solidez a ter uma vida sempre assombrada pela incerteza das coisas e dos estados humanos suscetíveis ao erro, ao medo e ao prazer, este último sempre acionado com o desprazer. Ana foge dos estados limites dos seres, não deseja viver de fato, apenas sobreviver, pois parece-lhe que "viver leva à morte." (LISPECTOR, 2016, p. 306). Tal alhear-se, ou fuga do real, não é uma característica particular da classe média, não é algo elitista, pelo contrário, é um estado no qual o ser estabelece uma muralha para ser contraposta à realidade que tanto o aflige ou limita o seu estar a viver sobrevivendo. $\mathrm{O}$ alhear-se é um estado de sobrevivência, de fuga ou de covardia, mas jamais um estado particular de uma classe social particular. A narrativa de Ana não se limita ao espaço social da personagem, algo sempre tende a extravasar, a levar o que se narra para outros caminhos do humano, do para-além humano, do humano visto fora de seu meio, do 

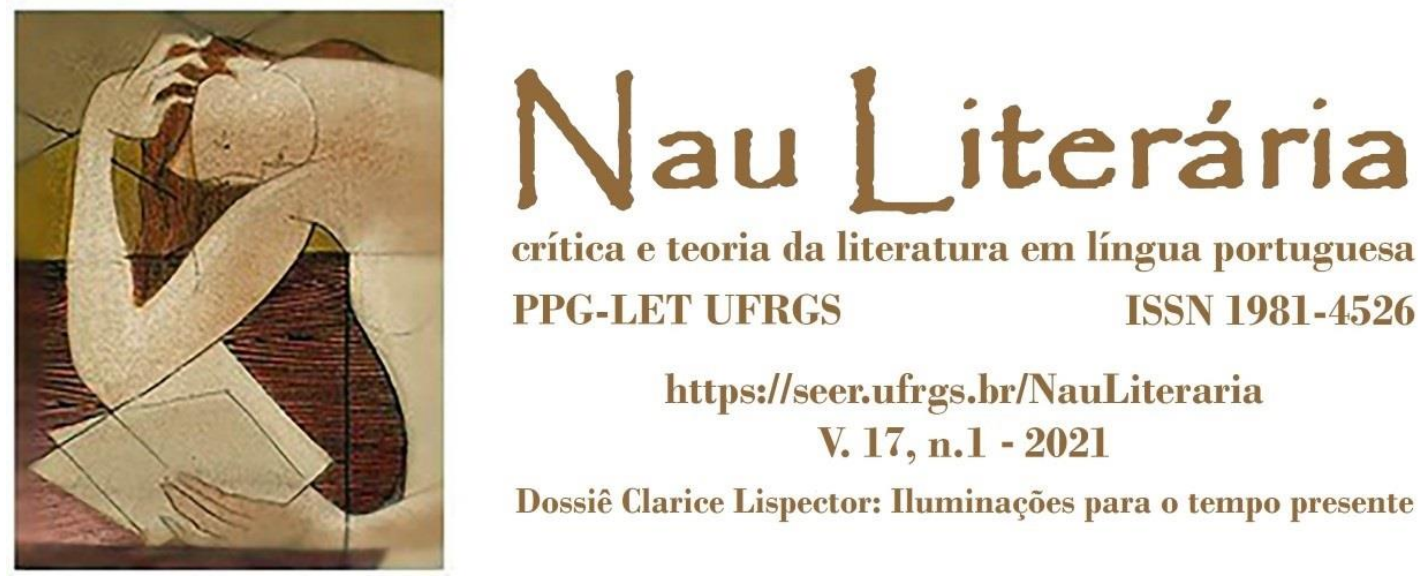

crítica e teoria da literatura em língua portuguesa

PPG-LET UFRGS

ISSN 1981-4526

$$
\begin{gathered}
\text { https://seer.ufrgs.br/NauLiteraria } \\
\text { V. 17, n.1 - } 2021
\end{gathered}
$$

Dossiê Clarice Lispector: Iluminações para o tempo presente

humano enquanto falta, covardia, amedrontamento, exilado em sua própria condição humana.

Sua preferência por uma vida asséptica e útil sujeita-a a uma fuga contínua todas as tardes, pois essa era a "hora perigosa" (LISPECTOR, 2020 a, p. 18), em que todas as suas tarefas domésticas estavam realizadas e nada mais ocupava funcionalmente a sua mente, o que poderia acabar por levá-la a refletir sobre a sua existência ou sobre o seu estar no mundo, o que a levaria consequentemente a estar consigo própria - e isso seria o fim de seu mundo forjado com tanto labor, o fim de sua existência de galinha: "Saía então para fazer compras ou levar objetos para consertar, cuidando do lar e da família à revelia deles. Quando voltasse era o fim da tarde e as crianças vindas do colégio exigiam-na.” (LISPECTOR, 2020 a, p. 19). Em uma dessas tardes de fuga, o seu belo embrulho é hediondamente rasgado pela visão de um cego que, em seu ato de mascar chicletes, aparentava sorrir-lhe e parar de sorrir-lhe em sua cegueira escura, como a rir de seu tolo embrulho que em nada era belo, mas artificial e pobre. O cego, que nada via, parecia the dizer da feiura do que Ana carregava no colo, o seu mundo embrulhado representado pelo saco de tricô que ela própria tinha feito, como um dom. Sentada no banco de um bonde, Ana se deixa transgredir pela visão destoante do cego, como se o ultrage lhe fosse inescapável agora diante daquele ser que corroía o celofane de seu parco e inútil embrulho. Repentinamente trazida à realidade pelo sentimento de uma piedade avassaladora em relação ao cego, Ana grita, como se estivesse novamente nascendo: "Ana deu um grito" (LISPECTOR, 2020 a, p. 20). Como uma galinha que perde o estado de galinha, Ana deixa cair no chão os ovos pelos quais era responsável: “o pesado saco de tricô despencou-se do colo, ruiu no chão [...]. Mas os ovos se haviam quebrado no embrulho de jornal." (LISPECTOR, 2020 a, p. 20). A gema, de um amarelo inaugural, escorre pelas linhas ásperas de sua sacola de tricô, como a placenta do corpo da mulher 


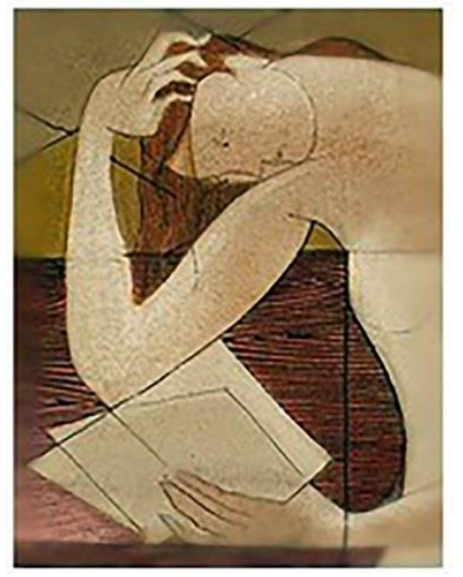

Nau Literária

crítica e teoria da literatura em língua portuguesa

PPG-LET UFRGS

ISSN 1981-4526

https://seer.ufrgs.br/NauLiteraria
V. 17, n.1 - 2021

Dossiê Clarice Lispector: Iluminações para o tempo presente

que dá à luz ou como o mundo que escorre por nossas mãos sem que nada possamos fazer para detê-lo.

Em “Amor”, a quebra dos ovos é a marca de uma drástica mudança temporal, espacial, discursiva e de estado: "Gemas amarelas e viscosas pingavam entre os fios da rede.” (LISPECTOR, 2020 a, p. 20). Embora, a meu ver, essa mudança não seja definitiva - o ovo quebrado meio que volta a ser o ovo perfeito ao final do conto, quando Ana apaga a perturbação e o excesso desse dia como se estivesse apagando a chama de uma vela com a ponta dos dedos, aparentemente escolhendo voltar ao estado de galinha: "Antes de se deitar, como se apagasse uma vela, soprou a pequena flama do dia." (LISPECTOR, 2020 a, p. 27). Apesar de todos os destroços de seu mundo particular, pelos quais precisou caminhar angustiada e desesperadamente até chegar à sua casa, Ana, após um rápido e incômodo retorno à rotina diária, ao antes-do-cego, cede à seguridade de seu mundo em ornamento, mas consciente de que não poderia sustentar outro estado senão o de galinha: “O que o cego desencadeara caberia nos seus dias?” (LISPECTOR, 2020 a, p. 26). Diante do espelho, ou melhor, diante de si e da sua imagem maculada pela visão do cego, a personagem, tendo experimentado o fascínio e o nojo provocados pela realidade do mundo, tocada ao extremo pela piedade, pelo ciclo vida-morte e morte-vida da natureza, ao se sentar ainda atordoada em um banco do Jardim Botânico, opta pelo conforto de uma sobrevida em um mundo artificial ao invés da vida-em-perigo de um mundo real, tão real que poderia mastigá-lo se assim desejasse: “A piedade pelo cego era tão violenta como uma ânsia, mas o mundo lhe parecia seu, sujo, perecível, seu. [...] Ela amava o mundo, amava o que fora criado - amava com nojo.” (LISPECTOR, 2020 a, p. 24). Mas Ana recua covardemente. E o seu mundo se perde talvez para sempre: "Acabara-se a vertigem de bondade. / E, se atravessara o amor e o seu inferno, penteava-se agora diante do espelho, por um instante sem nenhum mundo no coração." (LISPECTOR, 2020 a, p. 27). 


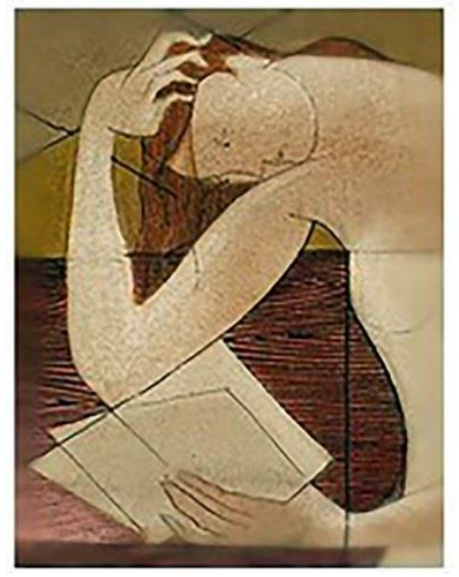

Nau Literária

crítica e teoria da literatura em língua portuguesa

PPG-LET UFRGS

ISSN 1981-4526

\author{
https://seer.ufrgs.br/NauLiteraria \\ V. 17, n.1 - 2021
}

Dossiê Clarice Lispector: Iluminações para o tempo presente

O amor ao que é aparentemente seguro poderia suplantar a vivacidade de um estar no mundo enquanto sujeito em potencial, e não enquanto objeto decorativo? O amor ao eu, à seguridade do eu, à proteção do eu, poderia suplantar uma violência prazerosa que, por vezes, estilhaçaria esse eu ou o eclodiria ao pô-lo em contato mais violento com um outro eu? Manter-se seguro, alheado ao máximo possível do mundo, é um ato de amorpróprio? Mas, se o amor é uma total perda de si e uma entrega quase sacrificial ao outro, esse amor somente pode ser experienciado na realidade do mundo, e não em sua projeção mais asséptica. Nessa perspectiva, Ana não abdica simplesmente da realidade do mundo, a personagem abdica, na verdade, do amor presente no mundo, um amor que, segundo a narradora do conto "O ovo e a galinha", é para os fortes, e não para os covardes:

Amor é quando é concedido participar um pouco mais. Poucos querem o amor, porque
amor é a grande desilusão de tudo o mais. E poucos suportam perder todas as outras
ilusões. Há os que se voluntariam para o amor, pensando que o amor enriquecerá a vida
pessoal. É o contrário: amor é finalmente a pobreza. Amor é não ter. Inclusive amor é a
desilusão do que se pensava que era amor.

(LISPECTOR, 2016, p. 309)

Em Laços de família, aquela que suporta a perda das ilusões e a assume enquanto moeda de troca para entrar em um mundo outro que não aquele metodicamente construído para se poder habitar é Laura, de “A imitação da rosa". Se Ana cede à ordem, Laura não cederá, pois ela reclamará para si uma vez mais a extravagância do viver que um dia experimentou e/ou experienciou, ainda que esse viver seja talvez um estado de loucura:

- Não pude impedir, disse ela, e a derradeira piedade pelo homem estava na sua voz, o último pedido de perdão que já vinha misturado à altivez de uma solidão já quase perfeita. Não pude impedir, repetiu entregando-lhe com alívio a piedade que ela com esforço conseguira guardar até que ele chegasse. Foi por causa das rosas, disse com modéstia.

(LISPECTOR, 2020 a, p. 49)

O estado de piedade, citado por Laura, movimenta singularmente essas duas narrativas, a de Ana e a sua, como uma chave de acesso à realidade do mundo ou à experiência do que se expõe e se excede, ao amor mesclado ao nojo que o ato próprio da vida reivindica - não há, se observarmos bem, uma assepsia no viver, mas uma deliberada 


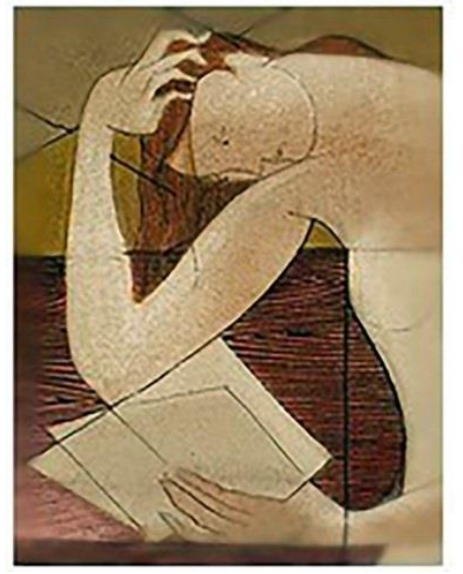

Nau Literária

crítica e teoria da literatura em língua portuguesa

PPG-LET UFRGS

ISSN 1981-4526

\author{
https://seer.ufrgs.br/NauLiteraria \\ V. 17, n.1 - 2021
}

Dossiê Clarice Lispector: Iluminações para o tempo presente

insalubridade no viver. Há, no mundo, o que Ana diz ao filho: "A vida é horrível, disselhe baixo, faminta." (LISPECTOR, 2020 a, p. 24). Nesses dois contos, a vida comunga contradição - o nojo e o fascínio, a loucura e a liberdade, a beleza e a sujidade, a claridade e a escuridão:

O que chamava de crise viera afinal. E sua marca era o prazer intenso com que olhava agora as coisas, sofrendo espantada. [...] $\mathrm{Na}$ Rua Voluntários da Pátria parecia prestes a rebentar uma revolução, as grades dos esgotos estavam secas, o ar empoeirado. Um cego mascando chicles mergulhara o mundo em escura sofreguidão. [...] E o cego? Ana caíra numa bondade extremamente dolorosa."

(LISPECTOR, 2020 a, p. 21)

Bondade que ao final do conto "Amor" será, como vimos, prontamente apagada como uma chama: à volta ao estado de galinha, assim, na verdade, "ela o quisera e escolhera." (LISPECTOR, 2020 a, p. 18). Nesse sentido, o estado de piedade é uma chave que dá acesso ao imprevisível, ao excesso, à extravagância e à imperfeição do mundo, porém, cabe ao indivíduo dispor dela ou não. Se Ana fecha a porta e volta-lhe às costas, Laura a escancara e adentra o seu espaço: “Assim como o vaga-lume acende. Já que não estava mais cansada, ia então se levantar e se vestir. Estava na hora de começar." (LISPECTOR, 2020 a, p. 47). Começar... a se despedir. Laura está disposta a sair de casa (da casca do ovo) enquanto Ana deliberadamente fica em casa (na casca do ovo), como em uma redoma de vidro: "estaria sempre sob a mesma redoma de vidro, sendo lentamente cozida em meu próprio ar viciado." (PLATH, 2019, p. 208), diria Esther, de A redoma de vidro, de Sylvia Plath, em um diálogo possível com Ana, de Lispector.

O primeiro passo em falso de Laura nos é apresentado pelo narrador do conto "A imitação da rosa" muito mais através do não dito, do que resta sob a letra, do que propriamente pelo dito, pelo que se diz abertamente, como se o cuidado com a palavra estivesse associado ao cuidado metódico da casa e da vida matrimonial ao qual Laura está novamente submetida - nada pode macular esse estado de normalidade, de alheamento do real, de ser galinha: "E ela mesma, enfim, voltando à insignificância com 


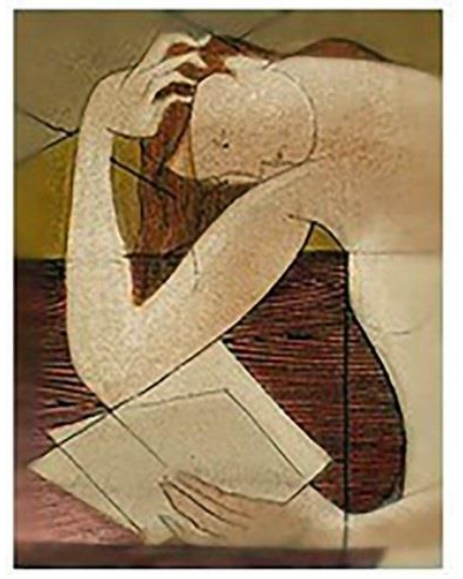

Nau Literária

crítica e teoria da literatura em língua portuguesa

PPG-LET UFRGS

ISSN 1981-4526

https://seer.ufrgs.br/NauLiteraria
V. 17, n.1 - 2021

Dossiê Clarice Lispector: Iluminações para o tempo presente

reconhecimento. [...] As pessoas felizmente ajudavam a fazê-la sentir que agora estava 'bem'." (LISPECTOR, 2020 a, p. 32-3). As reticências, as frases inacabadas, alguns reflexos espasmódicos de lembranças passadas e o medo constante de dar outra vez um passo em falso são marcas discursivas do conto que nos coloca, juntamente com Laura, em alerta: à espera de algo que espreita, embora ainda não saibamos, nem a personagem, de onde o perigo emana, apesar de suspeitarmos de sua presença vigilante. Por temer desagradar o marido e os amigos, Laura reassume o seu gosto pelo método no exercício impessoal dos afazeres domésticos, como uma fuga, semelhante à de Ana, de si, de sua individualidade, que poderia conduzi-la mais uma vez ao excesso e à perfeição: "Oh como era bom estar de volta, realmente de volta, sorriu ela satisfeita. [...] Passara a ferro as camisas de Armando, fizera listas metódicas para o dia seguinte, calculara minuciosamente o que gastara de manhã na feira, não parara na verdade um instante sequer." (LISPECTOR, 2020 a, p. 35). Manter-se ocupada é manter-se alheada, em estado de galinha. Em uma de suas memórias hospitalares, Laura confronta o seu estado anterior, de extravagância, com o estado de galinha resultante dos medicamentos ministrados a ela para o seu retorno à ordem do dia, à rotina metódica de uma dona de casa insignificante, porém, exemplar: "E, de volta à paz noturna da Tijuca - não mais aquela luz cega das enfermeiras penteadas e alegres saindo para as folgas depois de tê-la lançado como a uma galinha indefesa no abismo da insulina" (LISPECTOR, 2020 a, p. 38, grifos meus).

À base de medicamentos e de atividades precisas, como beber um copo de leite entre as refeições para diminuir a ansiedade, o seu estado de galinha poderia se manter estável - nisso acreditava o seu médico, o seu marido, os seus amigos e a própria Laura, embora esforçando-se bem mais do que os outros, a ponto de chegar a questionar as práticas de seu médico para a sua melhora: "Mas na sua humilde opinião uma ordem parecia anular a outra, como se lhe pedissem para comer farinha e assobiar ao mesmo tempo.” (LISPECTOR, 2020 a, p. 34). Cercada pelos móveis limpos, pelas roupas 


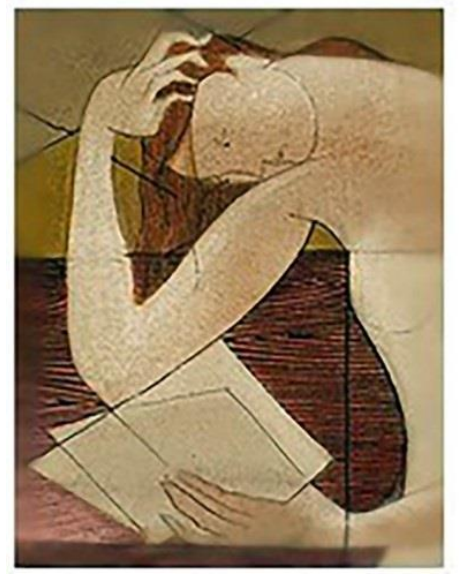

Nau Literária

crítica e teoria da literatura em língua portuguesa

PPG-LET UFRGS

ISSN 1981-4526

$$
\begin{gathered}
\text { https://seer.ufrgs.br/NauLiteraria } \\
\text { V. 17, n.1 - } 2021
\end{gathered}
$$

Dossiê Clarice Lispector: Iluminações para o tempo presente

engomadas, pela cozinha em ordem, por sua empregada e pela casa arrumada, Laura, ainda assim, em sua altruísta representação de uma pessoa que aparenta estar bem e sadia, parece deslocada nessa maquete tão rigorosamente pensada, modelada e organizada para ela: "Não, pensou de súbito vagamente avisada. [...] Era preciso nunca mais dar motivo para espanto, ainda mais com tudo ainda tão recente. E sobretudo poupar a todos o mínimo sofrimento da dúvida. [...] Nada de impulsos.” (LISPECTOR, 2020 a, p. 42). Dentro de Laura, algo excedia, fluía, como as gemas amarelíssimas escorriam entre os fios ásperos do saco de tricô de Ana. Mas, procurando refrear esses impulsos, Laura se agarrava à materialidade da rotina, à repetição ensaiada de como e com qual roupa iria ao primeiro encontro com os amigos após a sua chegada à casa-ovo-maquete - iria amarronzada: "Pois é. Era isso mesmo o que faria. E poria o vestido marrom com gola de renda creme. [...] Pois é. Poria o vestido marrom com gola de renda verdadeira." (LISPECTOR, 2020 a, p. 33-4). Entretanto, como um animal que investe sobre a sua presa, as rosas silvestres compradas mais cedo encaravam Laura e Laura as encarava, fascinada pela perfeição de sua cor e por seu estar no mundo, de uma extravagância irreprimível que ofuscava o tom amarronzado que os outros insistiam em colorir a sua vida.

Ao se deparar com a visão das rosas, "Nunca vi rosas tão bonitas, pensou com curiosidade.” (LISPECTOR, 2020 a, p. 40), Laura se deixa abrir em pétalas, mas não sem uma intensa batalha consigo própria. Um arriscado fluxo de consciência toma-lhe o corpo e a mente, a beleza inaudita das rosas é como um chamado ao retorno à extravagância, ao excesso, ao que se perde e falha, à pobreza do instante sofregamente devorado:

E quando olhou-as, viu as rosas.

E então, incoercível, suave, ela insinuou em si mesma: não dê as rosas, elas são lindas.

Um segundo depois, muito suave ainda, o pensamento ficou levemente mais intenso, quase tentador: não dê, elas são suas. Laura espantou-se um pouco: porque as coisas nunca eram dela. 


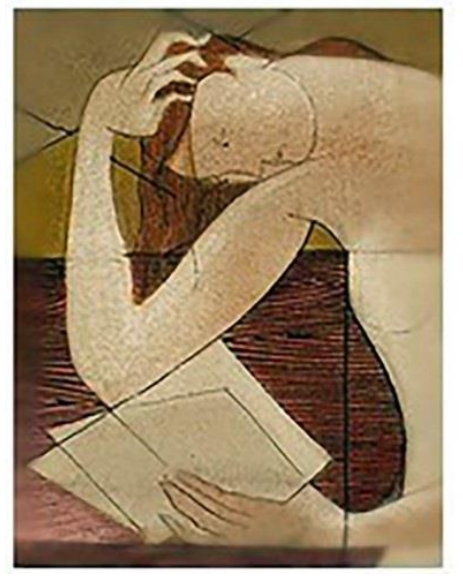

Nau Literária

crítica e teoria da literatura em língua portuguesa

PPG-LET UFRGS

ISSN 1981-4526

\author{
https://seer.ufrgs.br/NauLiteraria \\ V. 17, n.1 - 2021
}

Dossiê Clarice Lispector: Iluminações para o tempo presente

Mas estas rosas eram. Rosadas, pequenas, perfeitas: eram. Olhou-as com incredulidade: eram lindas e eram suas. Se conseguisse pensar mais adiante, pensaria: suas como nada até agora tinha sido.

E mesmo podia ficar com elas pois já passara aquele primeiro desconforto que fizera com que vagamente ela tivesse evitado olhar demais as rosas.

(LISPECTOR, 2020 a, p. 43)

As rosas eram suas do mesmo modo como o mundo era de Ana, após a visão do cego, com a única diferença de que Ana se privará do que é seu por direito conquistado e Laura lutará de todas as formas por manter em sua guarda o que é seu por direito adquirido, apesar de, em um primeiro rompante, ter desejado se desfazer das rosas, enviando-as, por meio de sua empregada, como presente à amiga Carlota. De início, a exuberância das rosas pôs Laura em alerta: "Mas, sem saber por quê, estava um pouco constrangida, um pouco perturbada. Oh, nada demais, apenas acontecia que a beleza extrema incomodava." (LISPECTOR, 2020 a, p. 41). O perigo que as rosas representavam para o seu estado metódico fez com que a personagem desejasse se desfazer delas imediatamente, como uma rápida solução para manter-se ainda sob o sistemático teto de sua casa-maquete, em estado de galinha, alheada da beleza extrema presente no mundo. Entretanto, “o mal estava feito." (LISPECTOR, 2020 a, p. 20). A redoma de vidro se estilhaçara, Laura se libertava e as rosas passavam a se refletir em seu corpo como a um espelho. Laura cedia à beleza das rosas em pétalas: "Como uma viciada, ela olhava ligeiramente ávida a perfeição tentadora das rosas, com a boca um pouco seca olhava-as.” (LISPECTOR, 2020 a, p. 46). Com bastante ansiedade e exasperação, e procurando respostas satisfatórias ao ato de se desfazer das rosas, Laura dá continuidade ao que prometera inicialmente: daria as rosas à Carlota. Sem a presença da beleza, apenas com a sua ausência cravada em seu ser como um imenso buraco, restará a Laura imitá-la. E, ao imitar as rosas, Laura abre a porta novamente e logo depois fecha-a atrás de si. Ela vai em busca do chamado das rosas, daquilo que excede e se perde, daquilo que faz do eu múltiplos eus, daquilo que alguns chamam também de loucura, do estado de loucura: “Calma e suave, ela disse: / - Voltou, Armando. Voltou.” (LISPECTOR, 2020 a, p. 49). 


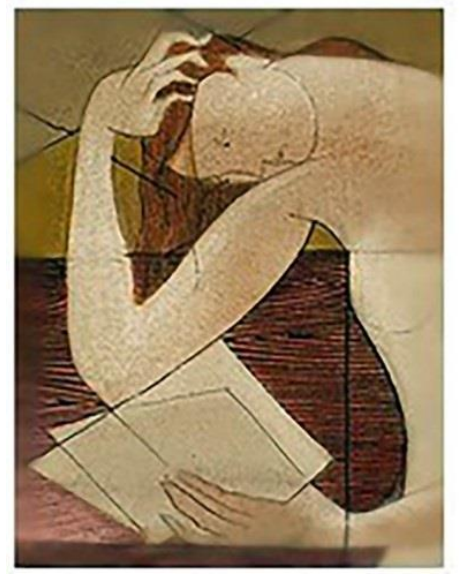

Nau Literária

crítica e teoria da literatura em língua portuguesa

PPG-LET UFRGS

ISSN 1981-4526

\author{
https://seer.ufrgs.br/NauLiteraria \\ V. 17, n.1 - 2021
}

Dossiê Clarice Lispector: Iluminações para o tempo presente

Bravamente, Laura entrega ao marido um bilhete final em formato de piedade e de perdão, e parte talvez para sempre:

Ela estava sentada com o seu vestidinho de casa. Ele sabia que ela fizera o possível para
não se tornar luminosa e inalcançável. Com timidez e respeito, ele a olhava. Envelhecido,
cansado, curioso. Mas não tinha uma palavra sequer a dizer. Da porta aberta via sua
mulher que estava sentada no sofá sem apoiar as costas, de novo alerta e tranquila como
num trem. Que já partira.

(LISPECTOR, 2020 a, p. 50)

Entre o ficar de Ana e a partida de Laura se encontra literalmente uma galinha com o seu ar constrangido. Na disposição dos treze contos que compõem o livro Laços de família, o texto "Uma galinha" está entre "Amor" e "A imitação da rosa" como a servir de eixo para os dois pratos da balança, que ora pendem para o alheamento total da realidade do mundo ora pendem para o rompimento com o mundo metódico e fabricado. Em "Uma galinha", o estado de fuga da galinha e em seguida o seu estado de acomodamento condensam os dois extremos dos contos que o antecede e o sucede, por isso o ar constrangido do animal, que se sabendo corajoso se deixa se acomodar, se sujeitar, a uma possibilidade de segurança aparente no seio de uma família de humanos, não mais se dispondo a fugir, a ganhar a liberdade, embora ainda sinta, mas não pense, o frescor do vento a golpear o seu bico:

Uma vez ou outra, sempre mais raramente, lembrava de novo a galinha que se recortara contra o ar à beira do telhado, prestes a anunciar. Nesses momentos enchia os pulmões com o ar impuro da cozinha e, se fosse dado às fêmeas cantar, ela não cantaria mas ficaria muito mais contente." (LISPECTOR, 2020 a, p. 30-1, grifos meus).

A galinha como um animal em instância, preso em ato, em um anúncio sem anunciação. Falta-lhe um imperativo para ser, uma exigência que lhe faça participante do mundo real, que lhe tire do sonho, do estado de sonho, que lhe faça parar de bicar o nada e ciscar o vazio. Por que a galinha bica tanto a terra? - pergunta-se a narradora do livro A vida íntima de Laura. A resposta: ela apenas bica por bicar, alheada do mundo e de suas próprias vontades, como um ser de exceção ou excessivo, que compromete o estado das coisas úteis: 


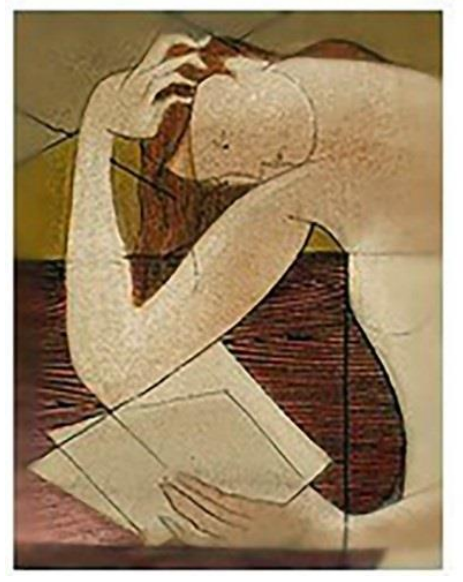

Nau Literária

crítica e teoria da literatura em língua portuguesa

PPG-LET UFRGS

ISSN 1981-4526

\author{
https://seer.ufrgs.br/NauLiteraria \\ V. 17, n.1 - 2021
}

Dossiê Clarice Lispector: Iluminações para o tempo presente

Por que será que Laura fica o dia inteiro bicando a terra e procurando comida? Não pode ser por tanta fome, pois a cozinheira Dona Luísa lhe dá muito milho. Vou contar um segredo de Laura: ela come por pura mania. Come cada porcaria! Mas não é tão burra assim. Por exemplo: não come pedaço de vidro. Sabida, hein?

(LISPECTOR, 2012, p. 17)

Pressupõe-se que tal esperteza, observada na galinha Laura, tenha feito a galinha de "Uma galinha" fugir, não por se saber uma galinha de almoço de domingo, mas por sentir talvez a ameaça daquilo que nomeamos a morte. Contudo, sua esperteza resta em ato, em instância, não realizável completamente e não resultando em algo específico, como, por exemplo, em sua total liberdade. Seria como se a sua esperteza apenas alcançasse um nível específico de disposição no espaço-tempo narrativo, algo faltandolhe para que completasse o ato de fuga. E nesse quase, a galinha é apanhada: "Afinal, numa das vezes em que parou para gozar sua fuga, o rapaz alcançou-a. Entre gritos e penas, ela foi presa. Em seguida carregada em triunfo por uma asa através das telhas e pousada no chão da cozinha com certa violência.” (LISPECTOR, 2020 a, p. 29). Está aí a tragicidade da galinha: o seu movimento interrompido, um contínuo viver em instância, que lhe faz sobreviver alheada no e do mundo, como se estivesse em uma realidade outra, fabricada por si própria, como o faz Ana: "Inconsciente da vida que lhe fora entregue, a galinha passou a morar com a família. [...] A galinha tornara-se a rainha da casa. Todos, menos ela, o sabiam." (LISPECTOR, 2020 a, p.30). E o narrador conclui: "Continuou entre a cozinha e o terraço dos fundos, usando suas duas capacidades: a de apatia e a do sobressalto.” (LISPECTOR, 2020 a, p. 30). O estar da galinha entre a cozinha e o terraço dialoga, em Laços de família, com as atividades domésticas impessoais e apáticas de Ana e de Laura, quando as duas pretendem pertencer a um mundo perfeitamente idealizado dentro do mundo real - este, diferente daquele, com sua realidade imperfeita, não decorativa e, por isso, harmônico em sua desarmonia desconcertante. $\mathrm{O}$ ir e vir apático da galinha nos ladrilhos da cozinha não deixa de ser uma bela metáfora do alienamento da dona de casa que se submete a manter a ordem do lar em detrimento de sua 

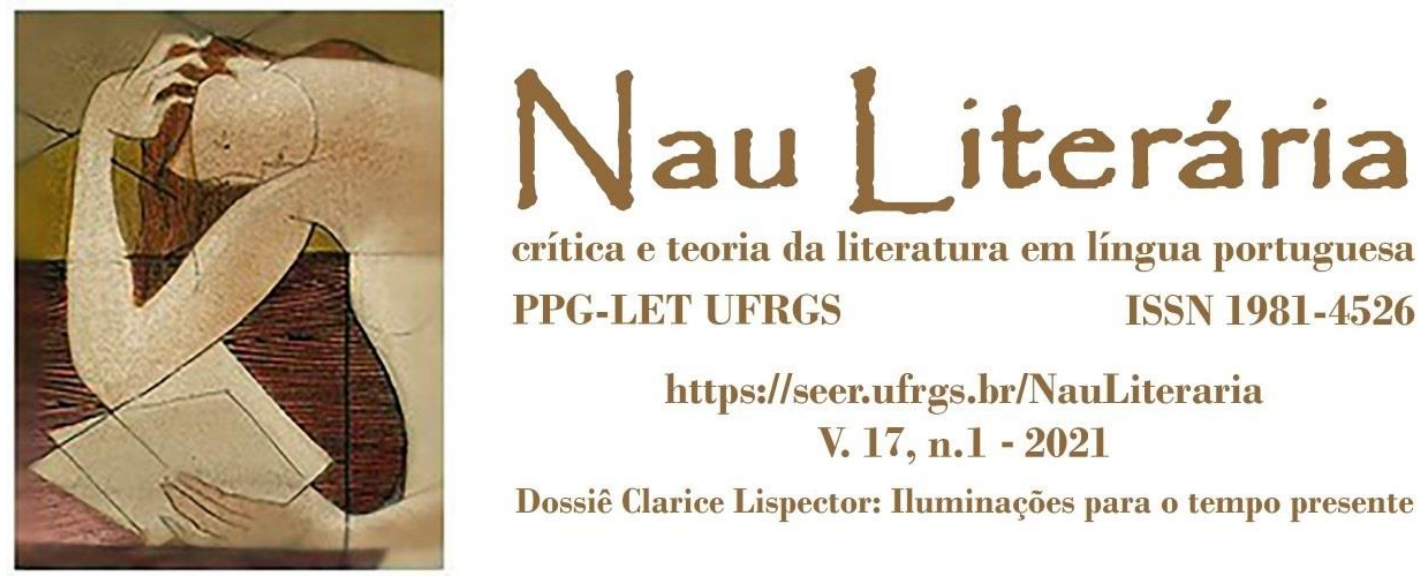

crítica e teoria da literatura em língua portuguesa

PPG-LET UFRGS

ISSN 1981-4526

$$
\begin{gathered}
\text { https://seer.ufrgs.br/NauLiteraria } \\
\text { V. 17, n.1 - } 2021
\end{gathered}
$$

Dossiê Clarice Lispector: Iluminações para o tempo presente

individualidade enquanto mulher, não me refiro enquanto esposa, mas enquanto mulher, um ser vivo que deseja, que sofre, que chora, e não uma esposa útil, de vitrine, tornada objeto dentre todos os objetos de sua casa decorativamente arrumada, como a de Ana: "Todo o seu desejo vagamente artístico encaminhara-se há muito no sentido de tornar os dias realizados e belos; com o tempo seu gosto pelo decorativo se desenvolvera e suplantara a íntima desordem." (LISPECTOR, 2020 a, p.18).

Entre a cozinha e o restante da casa decorada, Ana dispunha de seu tempo, preenchendo-o com tarefas cada vez mais aperfeiçoadas e, por essa razão, mais alienantes e mais deformadoras do real: "A cozinha era enfim espaçosa, o fogão enguiçado dava estouros.” (LISPECTOR, 2020 a, p. 17). Entre a cozinha e a sala-maquete, Laura, a quasegalinha, prontificava-se a atender aos desejos dos outros, seguindo um "roteiro de bemestar":

Encaminhou-se para a cozinha e, como se tivesse culposamente traído com seu descuido Armando e os amigos devotados, ainda junto da geladeira bebeu os primeiros goles com um devagar ansioso, concentrando-se em cada gole com fé como se estivesse indenizando a todos e se penitenciando. (LISPECTOR, 2020 a, p. 34)

Se, por um lado, os textos claricianos reiteram a inutilidade da galinha para si própria, como podemos destacar uma vez mais da leitura de "Uma galinha": "A galinha é um ser. É verdade que não se poderia contar com ela para nada. Nem ela própria contava consigo, como o galo crê na sua crista." (LISPECTOR, 2020 a, p. 29); por outro lado, e divergindo do narrador deste conto, a galinha nos é útil sim e com ela podemos contar para a nossa sobrevivência, pois o ser galinha produz, independentemente de saber ou não que está gerando algo em seu interior, o ovo. A galinha dá à luz o ovo - e nisto está a sua utilidade, o seu caráter útil na maquinaria do mundo, embora essa utilidade a torne muito mais invisível do que visível: nos acostumamos a ver a galinha como produto doméstico, e não como animal doméstico. Essa diferença aparenta ser pequena, mas é devastadoramente enorme - não nos foi repassado enquanto costume e tradição fazer, por exemplo, carinhos em uma galinha, como nos acostumamos a fazer em outros animais de 


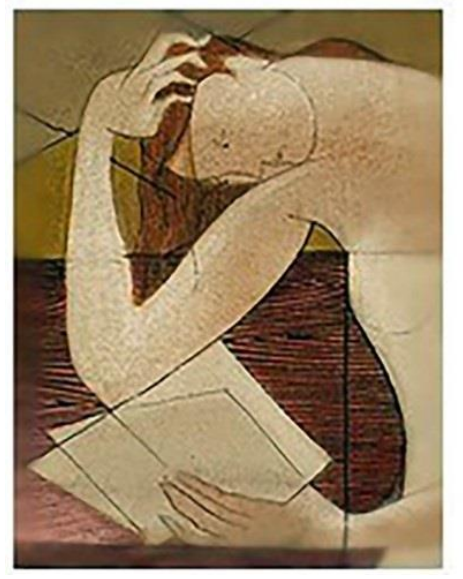

Nau Literária

crítica e teoria da literatura em língua portuguesa

PPG-LET UFRGS

ISSN 1981-4526

$$
\begin{gathered}
\text { https://seer.ufrgs.br/NauLiteraria } \\
\text { V. 17, n.1 - } 2021
\end{gathered}
$$

Dossiê Clarice Lispector: Iluminações para o tempo presente

estimação: "Nunca ninguém acariciou uma cabeça de galinha." (LISPECTOR, 2020 a, p. 30), comenta o narrador do conto "Uma galinha". Possivelmente por viver em sobressaltos, assustada, como Laura, de A vida íntima de Laura?: "Laura quase não deixa gente nenhuma fazer carinho nela. Porque tem um medo danado de pessoas. [...] Ela cacareja assim: - NÃO ME MATEM! NÃO ME MATEM!” (LISPECTOR, 2012, p. 13). Esse temor de Laura, provavelmente compartilhado por todas as galinhas, pois todas vivem em instância, talvez seja o elemento instintual que fizera a galinha de domingo fugir, apesar de que nunca "se adivinharia nela um anseio" (LISPECTOR, 2020 a, p. 28), uma vez que parecia totalmente "estúpida, tímida." (LISPECTOR, 2020 a, p. 29). Ou talvez por sentir o seu destino já de antemão prefigurado para a morte, como produto doméstico para a subsistência de homens e de mulheres, a galinha não se deixe acarinhar, nem amar, tampouco se amar, como se confirma na crônica "Uma história de tanto amor", presente em A descoberta do mundo: "As galinhas pareciam ter uma presciência do próprio destino e não aprendiam a amar os donos nem o galo. Uma galinha é sozinha no mundo.” (LISPECTOR, 2020, p. 157).

A solidão da galinha, como pondera a menina que tanto a amava na crônica "Uma história de tanto amor", ecoa, se observarmos bem, a solidão de Ana e a solidão de Laura antes da visão das rosas. Há, em suas existências compartilhadas, uma solidão essencial, um estar no mundo em sobrevida, jamais em existência plena, como que apartadas da experiência legítima com o outro, pois o outro demanda sentimentos, e sentir plenamente poderia levá-las ao erro da felicidade (Ana), da extravagância (Laura) e da liberdade (galinha). Deixar-se sentir é estar no mundo e nem todos, como diz a narradora de "O ovo e a galinha", estão prontos para a exigência do existir, ou do amar: "Mas na sua vida não havia lugar para que sentisse ternura pelo seu espanto - ela [Ana] o abafava com a mesma habilidade que as lides em casa lhe haviam transmitido." (LISPECTOR, 2020 a, p. 19). Alhear-se do mundo real, preenchendo os dias com os trabalhos domésticos, não deixa de 

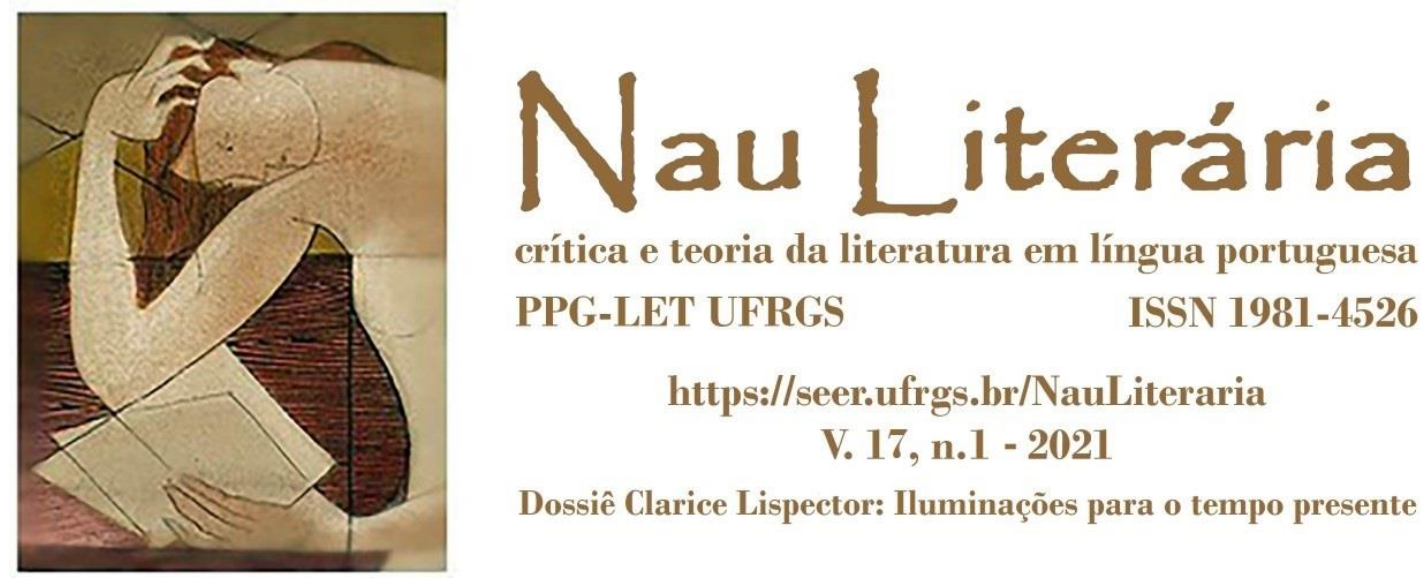

crítica e teoria da literatura em língua portuguesa PPG-LET UFRGS

ISSN 1981-4526

$$
\begin{gathered}
\text { https://seer.ufrgs.br/NauLiteraria } \\
\text { V. 17, n.1 - } 2021
\end{gathered}
$$

Dossiê Clarice Lispector: Iluminações para o tempo presente

ser um estado de fuga, de galinha, de covardia, ou de extrema coragem, talvez, mas que resulta, sobretudo, em um afastar-se de si e do outro, resulta em solidão: “e [a galinha] circulava pelo ladrilho, o corpo avançando atrás da cabeça, pausado como num campo, embora a pequena cabeça a traísse: mexendo-se rápida e vibrátil, com o velho susto de sua espécie já mecanizado.” (LISPECTOR, 2020 a, p. 30). E solitariamente a galinha/mulher dá à luz o ovo/o ser. E esse ato de parir sozinha é o que, momentaneamente, salva a vida da galinha de domingo, do conto "Uma galinha": "Foi então que aconteceu. De pura afobação a galinha pôs um ovo. Surpreendida, exausta. Talvez fosse prematuro. Mas logo depois, nascida que fora para a maternidade, parecia uma velha mãe habituada." (LISPECTOR, 2020 a, p. 29). Enquanto servia à família com os seus ovos, a galinha era mantida viva, porém, quando deixou de ser útil, ou pela idade já avançada, mataram-na e serviram-na no almoço: "Até que um dia mataram-na, comeram-na e passaram-se anos.” (LISPECTOR, 2020 a, p. 31).

A utilidade da galinha, como útil poedeira, é mais abertamente verbalizada em $A$ vida íntima de Laura: "Mas ninguém tem intenção de matá-la porque ela [Laura] é a galinha que bota mais ovos em todo o galinheiro e mesmo nos das vizinhanças." (LISPECTOR, 2012, p. 13). E, vejamos, neste livro, não apenas a sua utilidade como também o seu destino para a morte é dito de modo mais enfático: “- Essa galinha [Laura] já não está botando muito ovo e está ficando velha. Antes que pegue alguma doença ou morra de velhice a gente bem que podia fazer ela ao molho pardo.” (LISPECTOR, 2012, p. 34). Com A vida íntima de Laura, a escrita clariciana apresenta ao seu leitor duas questões essenciais à sua compreensão enquanto indivíduo participante do mundo ou que se deseja participante do mundo: a utilidade/inutilidade de um ser e a morte de um ser em benefício de sua própria sobrevivência. Saber lidar com a morte do outro é um dos pontos fortes deste livro, principalmente quando a nossa sobrevivência está em jogo: até que ponto o outro pode fornecer a si próprio como alimento para o nosso bem-estar? É certo 


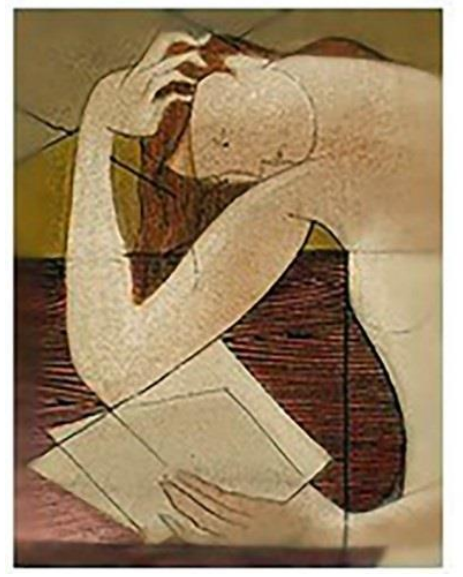

Nau Literária

crítica e teoria da literatura em língua portuguesa

PPG-LET UFRGS

ISSN 1981-4526

$$
\begin{gathered}
\text { https://seer.ufrgs.br/NauLiteraria } \\
\text { V. 17, n.1 - } 2021
\end{gathered}
$$

Dossiê Clarice Lispector: Iluminações para o tempo presente

matar para comer? A galinha sofre? Ou sente que sofre? Há sentimentos em uma galinha?: "É engraçado gostar de galinha viva mas ao mesmo tempo também gostar de comer galinha ao molho pardo. É que pessoas são uma gente meio esquisitona." (LISPECTOR, 2012, p. 32). Uma resposta não satisfatória, claro, embora ela esteja de acordo com a insatisfação de toda a escrita clariciana quando o tema do ser galinha e/ou do estado de galinha se apresenta em sua estrutura discursiva: “A partir daí compreende-se por quê, apesar da plumagem e da capacidade de fazer 'um ovo certo', Laura não possa representar a integridade dos heróis." (ARÊAS, 2005, p. 127). Assim como a galinha, a escrita que a acompanha também está em instância de anunciar algo que logo depois escapa. O ser galinha excede, é não domesticável. A galinha é a escrita clariciana que escapa, pois inapreensível. A galinha, então, se torna a verdadeira Esfinge da obra de Clarice Lispector, e não a pessoa de Clarice Lispector, como muitos de seus leitores acreditam: "Vi a Esfinge. Não a decifrei. Mas ela também não me decifrou. Encaramo-nos de igual para igual. Ela me aceitou, eu a aceitei. Cada uma com o seu mistério.” (LISPECTOR, 2020, p. 453).

Não deciframos a galinha e, assim, continuamos a nos perguntar, como a narradora da crônica "Sou uma pergunta", de A descoberta do mundo: "Por que existe a galinha?" (LISPECTOR, 2020, p. 476).

\section{0 bastante outro do humano: os animais, ou seja, a galinha}

Como dizer que os bibelôs estavam ali? ah! fitou ela com brutalidade essas coisas feitas das próprias coisas, falsamente domesticáveis, galinhas que comem por vossas mãos mas não vos reconhecem - apenas emprestadas, uma coisa emprestada à outra e a outra emprestada à outra. Conservando-se sobre as prateleiras ou mantendo-se indiferentemente no chão e no teto impessoais e orgulhosas como um galo. Pois tudo o que fora criado fora ao mesmo tempo desencadeado.

(A cidade sitiada. Clarice Lispector) 


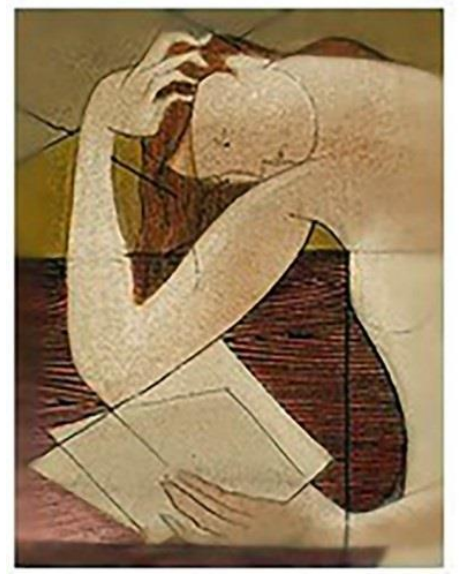

Nau Literária

crítica e teoria da literatura em língua portuguesa

PPG-LET UFRGS

ISSN 1981-4526

https://seer.ufrgs.br/NauLiteraria
V. 17, n.1 - 2021

Dossiê Clarice Lispector: Iluminações para o tempo presente

Em "Bichos (I)", presente em A descoberta do mundo, a narradora da crônica, de imediato, logo na abertura de seu texto, escreve: “às vezes me arrepio toda ao entrar em contato físico com bichos ou com a simples visão deles." (LISPECTOR, 2020, p. 427, grifos meus). E conclui a sua reflexão: "Pareço ter certo medo e horror daquele ser vivo que não é humano e que tem os nossos mesmos instintos, embora mais livres e mais indomáveis." (LISPECTOR, 2020, p. 427, grifos meus). Dar início à sua crônica tipograficamente com a letra minúscula quando se está propondo uma reflexão sobre a estranheza provocada diante de um animal, e mais, diante da visão de um animal (ele que nos olha e nós que o olhamos) é bastante significativo, pois, ao retomar a conhecida diferença entre o humano e o animal, a narradora dá a ver, por meio da minúscula, que a suposta superioridade do humano em relação ao animal precisa ser revista e revisitada, ou melhor, desconstruída de dentro do que se pensa ser o animal e do que se pensa poder sobre o animal, como se o animal fosse um objeto à disposição do humano, e nada melhor do que o ser galinha ou o estado de galinha em Lispector para fazer ruir os conceitos estritamente enraizados e dados como verdadeiros sobre a ideia que se tem do animal, até porque "as relações entre homem e bicho são singulares, não substituíveis por nenhuma outra.” (LISPECTOR, 2020, p. 429). Poder sobre o animal ou humanizá-lo, eis outra questão desta crônica: "Mas eu não humanizo os bichos, acho que é uma ofensa - há de respeitar-lhes a natura - eu é que me animalizo. Não é difícil, vem simplesmente, é só não lutar contra, é só entregar-se.” (LISPECTOR, 2020, p. 430). Por que não animalizar o humano? Por que não se deixar tentar pelo que não se sabe do animal? Por que não invertemos os elementos em questão? São essas algumas propostas de reflexão que a narradora de "Bichos (I)" nos propõe como provocação, a começar pelo seu início em minúscula.

Os bichos são "mais livres e mais indomáveis", então, como se pode querer domesticar o indomesticável? Domesticar o que não se compreende, essa é a grande 


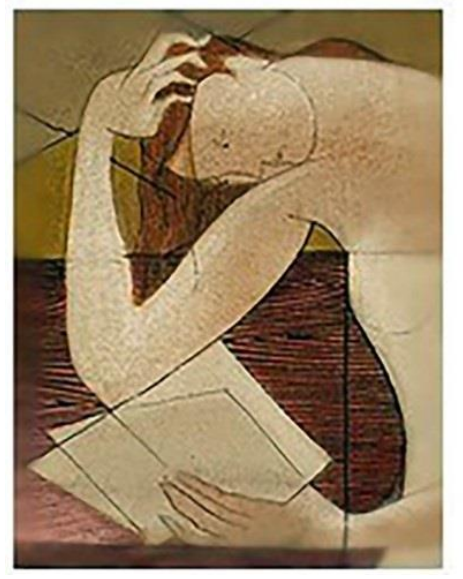

Nau Literária

crítica e teoria da literatura em língua portuguesa

PPG-LET UFRGS

ISSN 1981-4526

$$
\begin{gathered}
\text { https://seer.ufrgs.br/NauLiteraria } \\
\text { V. 17, n.1 - } 2021
\end{gathered}
$$

Dossiê Clarice Lispector: Iluminações para o tempo presente

aporia do humano. No verão de 1997, Jacques Derrida, em uma conferência em Cerisy que mais tarde ganhou a forma de um livro, $O$ animal que logo sou, confere ao animal um estar no mundo enquanto um estar da diferença, algo ainda não pensado pela filosofia, tampouco pela ciência - um pensamento a partir do animal e não a partir do humano para o animal, como se houvesse uma hierarquia de poderes, e uma legítima superioridade do humano frente ao animal: "Nada poderá tirar de mim, nunca, a certeza de que se trata de uma existência [a do animal] rebelde a todo conceito.” (DERRIDA, 2002, p. 26). Os animais: rebeldia e o que se demora indomável. Nessa proposta, Lispector e Derrida apontam para o que ainda resta de muito inapreensível sobre os animais - a sua própria existência enquanto animais e o seu estar no mundo que sofre com a intransigência do humano se desejar sempre se colocar em primeiro plano, em maiúscula, jamais em minúscula: "Ela [negar a possibilidade do animal ver o homem] institui o próprio do homem, a relação consigo de uma humanidade antes de mais nada preocupada com seu próprio e ciumenta em relação a ele." (DERRIDA, 2002, p. 34). Segundo Derrida, negar a capacidade de visão dos animais sobre o humano, uma possível compreensão daquele sobre este, é um modo de proteção do humano que toma duas frentes: a não sujeição ao animal e o assujeitamento do animal, como um instinto (animal) que pressupõe a demarcação de seu território na natureza. O humano, quer se queira ou não, mata (dispõe da vida dos) os animais de diversos modos, seja por sobrevivência ou por matar por matar, como a demarcar (novamente), não sejamos ingênuos de pensar o contrário, a sua superioridade. Porém, se nos atermos à leitura da Bíblia, constataremos que o homem veio depois dos animais - seria, então, esse ato de subjugação um ato ciumento, provoca Derrida: "Quem nasceu primeiro, antes dos nomes? Quem viu chegar o outro em seu território, há muito tempo? Quem terá sido o primeiro ocupante, e portanto o senhor? O sujeito? Quem continua, há muito tempo, sendo o déspota?” (DERRIDA, 2002, p. 39). 


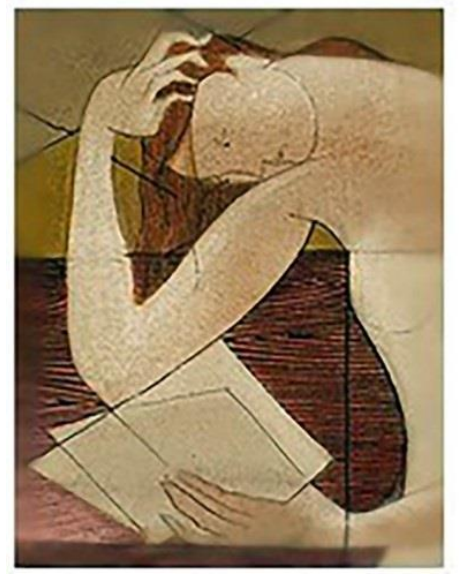

Nau Literária

crítica e teoria da literatura em língua portuguesa

PPG-LET UFRGS

ISSN 1981-4526

\author{
https://seer.ufrgs.br/NauLiteraria \\ V. 17, n.1 - 2021
}

Dossiê Clarice Lispector: Iluminações para o tempo presente

Quando o humano nega a possibilidade de os animais poderem vê-lo e, assim, compreendê-lo à sua maneira, é temer a si próprio. Ou seja, é temer pôr a sua humanidade ou o que lhe torna humano em questão: "Quem se recusa à visão de um bicho está com medo de si próprio.” (LISPECTOR, 2020, p. 429). Em “O crime do professor de matemática", de Laços de família, é exatamente a consciência de que o cão o olha e o assimila enquanto ser que faz com que o professor o abandone em uma cidade distante, sendo este o seu crime: "“De mim, exigias que eu fosse um homem. E eu, eu disfarçava como podia. Às vezes, sentado sobre as patas diante de mim, como me espiavas!"” (LISPECTOR, 2020 a, p. 116). O olhar do cão, preâmbulo para o seu quase-assassinato: “"Eu então olhava o teto, tossia, dissimulava, olhava as unhas. Mas nada te comovia: $t u$ me espiavas." (LISPECTOR, 2020 a, p. 116-7, grifos meus). Deixar um cão que se criou desde pequeno na sarjeta, decerto, é um crime, porém, um crime que neutralizou um outro ainda maior, o seu assassinato, tamanha a exigência que o seu olhar demandava do professor: "“E este crime substitui o crime maior que eu não teria coragem de cometer', pensou o homem cada vez mais lúcido.” (LISPECTOR, 2020 a, p. 118). Enquanto procurava se redimir de seu crime dando a outro cão um sepultamento digno, um cão negro encontrado morto em uma esquina, o professor em um doloroso fluxo de consciência retoma, em uma espécie de mea-culpa, momentos de convivência com o cão, um cão que, ao tornar-se um ser que lhe exigia ser um ser, não algo humanizado ou domesticável, mas um ser, com a dignidade de um ser tal qual o seu dono, passa a ser visto constantemente como " "um cão que se podia abandonar."” (LISPECTOR, 2020 a, p. 116). Ao ser visto pelo cão, o professor tem as suas verdades sobre a domesticidade do animal (ou o seu assujeitamento) e a sua suposta superioridade diante do ser animal deliberadamente abaladas, tornando-se consciente de que: “Agora estou bem certo de que não fui eu quem teve um cão. Foste tu que tiveste uma pessoa."' (LISPECTOR, 2020 a, p. 117). 


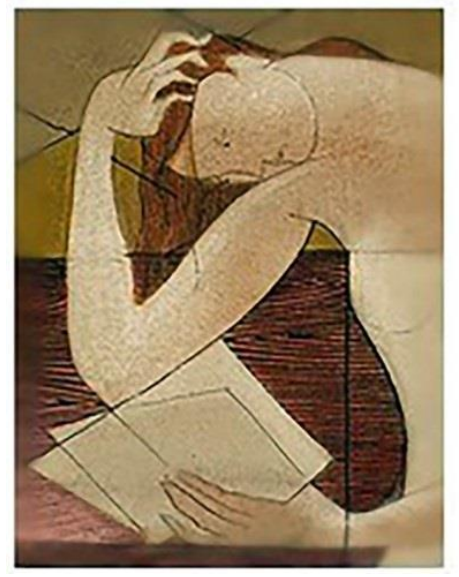

Nau Literária

crítica e teoria da literatura em língua portuguesa

PPG-LET UFRGS

ISSN 1981-4526

\author{
https://seer.ufrgs.br/NauLiteraria \\ V. 17, n.1 - 2021
}

Dossiê Clarice Lispector: Iluminações para o tempo presente

Ter essa consciência lhe exigia novos hábitos, novos olhares e novas perspectivas com as quais ele não estava pronto para lidar, sendo preferível então abandonar o cão: “Não me pedindo nada, me pedias demais.” (LISPECTOR, 2020 a, p. 116). Essa impossível partilha do se saber ser entre o humano e o animal, segundo Derrida, problematiza o limite, o estado limite, entre o que se entende por humano e por animais, bem como abre para que esse mesmo limite possa ser repensado e, em alguns pontos, desconstruído, dando à compreensão dos animais, e ao trato com estes, um caráter profundamente mais ético e político:

Como todo olhar sem fundo, como os olhos do outro, esse olhar dito "animal" me dá a ver o limite abissal do humano: o inumano ou o a-humano, os fins do homem, ou seja, a passagem das fronteiras a partir da qual o homem ousa se anunciar a si mesmo, chamando-se assim pelo nome que ele acredita se dar. (DERRIDA, 2002, p. 31).

Estar diante do outro-animal, ou deixar-se ver pelo animal, é, por vezes, ouvir um chamado ao qual não se pode responder totalmente - a entrega será sempre fracassada, por mais que desejemos nos confundir com o outro-animal, pois o espaço do outro nos é interdito. O outro se configura, como bem afirma Emmanuel Levinas, em Le temps et l'autre, como um mistério excedente, que resta inapreensível e distante: "A relação com o outro não é uma idílica e harmoniosa relação de comunhão, nem uma simpatia pela qual nos pondo em seu lugar o reconhecemos como semelhante a nós, mas exterior a nós; a relação com o outro é uma relação com um Mistério.” (LEVINAS, 2011, p. 63, tradução minha). Porém, tanto para Lispector quanto para Derrida, o bastante outro do homem não é o homem e/ou Deus, como acredita Levinas - para os dois autores, o completamente outro do homem é os animais: "Sim, do completamente outro, mais outro que qualquer outro e que eles chamam um animal" (DERRIDA, 2002, p. 29, grifo do autor). Em "Bichos (Conclusão)", presente em A descoberta do mundo, diz a narradora em diálogo cerrado com Derrida: "Eles [os bichos] às vezes clamam do longe de muitas gerações e eu não posso responder senão ficando desassossegada. É o chamado.” (LISPECTOR, 2020, p. 434). 


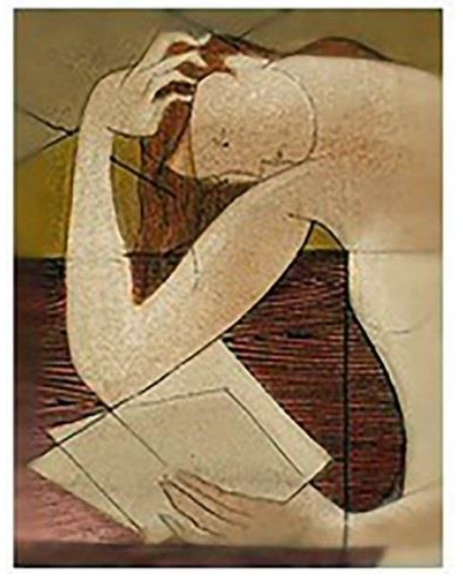

Nau Literária

crítica e teoria da literatura em língua portuguesa

PPG-LET UFRGS

ISSN 1981-4526

$$
\begin{gathered}
\text { https://seer.ufrgs.br/NauLiteraria } \\
\text { V. 17, n.1 - } 2021
\end{gathered}
$$

Dossiê Clarice Lispector: Iluminações para o tempo presente

Diante da alteridade excedente do outro-animal, diversas são as condutas e as ações do humano: apesar da possibilidade do viver-com, há outras mais complexas e mais agressivas, como, por exemplo, o abandono do animal ou o seu assassínio por pura e deliberada incompreensão de sua excedência, como no caso da menina Ofélia, do conto “A legião estrangeira", de Lispector: "Devagar empurrei a máquina. Relutante fui afastando devagar as cadeiras do caminho. Até parar devagar à porta da cozinha. No chão estava o pinto morto. Ofélia! chamei num impulso pela menina fugida." (LISPECTOR, 2016, p. 365). Em um relato em primeira pessoa, a narradora do conto, ao ter em mãos um pintinho amarelo que acabara de chegar à sua casa "por mão que queria ter o gosto de me dar coisa nascida.” (LISPECTOR, 2016, p. 349), prontamente se desloca para o seu passado e revive, como se este fosse o seu presente, a cena do assassinato do pintinho amarelo pelas mãos infantis de uma criança estrangeira: "Então estendi a mão e peguei o pinto. / Foi nesse instante que revi Ofélia. E nesse instante lembrei-me de que fora a testemunha de uma menina." (LISPECTOR, 2016, p. 352). Em “A legião estrangeira”, o adjetivo estrangeiro se estende tanto ao imaginário da narradora, quando ela se refere ao aspecto trigueiro, estrangeiro, da criança e de sua família, como se fossem das tribos hindus ou seus descendentes, quanto à relação estrangeira, estranha/incomum/singular, da criança com a narradora, e, sobretudo, do estranhamento que a presença do pintinho amarelo causa na estrangeira menina hindu. Nesse caleidoscópio de estranhamentos, o que resta patente é a impossibilidade de se manter um contato não-estrangeiro, ou completamente compreensível, com o outro, seja ele humano ou animal, principalmente se o outro for o outro-animal: um indefeso pinto amarelo.

Para uma menina que, frente a uma adulta, se comportava hierarquicamente como se compreendesse a vida mais e melhor, para a qual todas as perguntas tinham respostas, e respostas acessíveis, e que se dispunha a dar conselhos apesar de não lhe ser pedido nenhum - "Ofélia, ela dava-me conselhos. Tinha opinião formada a respeito de tudo. 


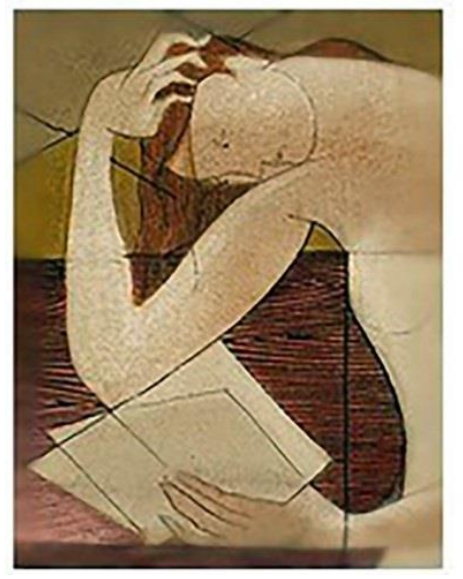

Nau Literária

crítica e teoria da literatura em língua portuguesa

PPG-LET UFRGS

ISSN 1981-4526

$$
\begin{gathered}
\text { https://seer.ufrgs.br/NauLiteraria } \\
\text { V. 17, n.1 - } 2021
\end{gathered}
$$

Dossiê Clarice Lispector: Iluminações para o tempo presente

Tudo o que eu fazia era um pouco errado, na sua opinião. Dizia 'na minha opinião' em tom ressentido, como se eu lhe devesse ter pedido conselhos e, já que eu não pedia, ela dava.” (LISPECTOR, 2016, p. 355) -, para ela, estar diante de um pintinho amarelo que excedia a sua compreensão, que não se deixava apreender em sua singularidade aparentemente compreensível e frágil, era estar diante de uma confusa e estranha coisa sem resposta, que não se dava à resposta e que escapava à resposta: "Da cozinha voltou imediatamente - estava espantada, sem pudor, mostrando na mão o pinto, e numa perplexidade que me indagava toda com os olhos: / - É um pintinho! disse." (LISPECTOR, 2016, p. 363, grifos meus). Em sua aparente adoração pelo pintinho, a menina, após entreter-se com o animal, resolve devolvê-lo à cozinha. Mas algo entre a sua ida e a sua volta soçobra irredutível, algo escapou ao tempo e à narradora ocupada em sua máquina de escrever. A menina voltara mudada, mais crescida, mais sombria e mais calada: "Não vi quando foi, não vi quando voltou. Em algum momento, por acaso e distraída, senti há quanto tempo havia silêncio. Olhei-a um instante. Estava sentada, de dedos cruzados no colo. Sem saber exatamente por quê, olhei-a uma segunda vez" (LISPECTOR, 2016, p. 364). Ofélia executara o crime que o professor de matemática não ousara executar, "cuja cena ninguém vê, nem a narradora sugere, pois fica no espaço do silêncio, do inenarrável.” (GOTLIB, 2013, p. 431). No entanto, para essa menina de oito anos, o outro-animal precisava morrer, pois escapava à sua compreensão e, para quem sabia tudo, o que não pode ser compreendido deve ser eliminado como se elimina uma erva daninha de um belo jardim tão sabiamente cultivado.

Ofélia mata o pintinho não por amá-lo demais, como acreditou a narradora do conto, nem por ódio, mas por incompreensão - por não compreender a sua existência animal, a menina mata-o. Por outro lado, mata-se o outro-animal por amá-lo demais, por excesso de zelo, como ocorre com a menina da crônica "Uma história de tanto amor". Por amor às suas duas galinhas, Pedrina e Petronilha, a menina doava-se por completo a elas 


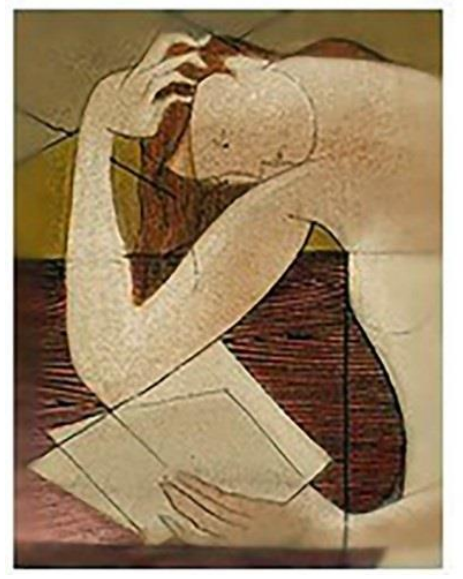

Nau Literária

crítica e teoria da literatura em língua portuguesa

PPG-LET UFRGS

ISSN 1981-4526

https://seer.ufrgs.br/NauLiteraria
V. 17, n.1 - 2021

Dossiê Clarice Lispector: Iluminações para o tempo presente

em cuidados extremos, sempre atenta à sua saúde e ao seu conforto. Um dia, Pedrina, aparentando mal-estar, foi devidamente enrolada e posta em cima de tijolos quentes pela menina que procurava aquecê-la, embora todos à sua volta dissessem que ela estaria na verdade apressando a morte do animal: "Quando na manhã seguinte Pedrina amanheceu dura de tão morta, a menina só então, entre lágrimas intermináveis, se convenceu de que apressara a morte do ser querido." (LISPECTOR, 2020, p. 156). Desde esse dia, o seu amor pelas galinhas amadurecera, tornando-se menos romântico e mais realista, pois "era o amor de quem já sofreu por amor." (LISPECTOR, 2020, p. 156). Por ter sofrido de tanto amor e por ter sabido do fim de Petronilha, que antes de Pedrina tinha sido servida como almoço em sua ausência, o destino das galinhas é como que descortinado em sua frente - segundo o que compreendera, a galinha tinha como único destino a morte, uma morte solitária: "E quando chegou a vez de Eponina [sua outra galinha] ser comida, a menina não apenas soube como achou que era o destino fatal de quem nascia galinha." (LISPECTOR, 2020, p. 156-7). Talvez o destino fatal das galinhas isente Ofélia de seu crime, pois, para um ser nascido para morrer, ter a sua morte antecipada não é nenhum grande mal, afinal, galinha não é um animal doméstico, mas um produto doméstico, com fins bastante precisos.

Nos textos claricianos, a galinha como o outro-excedente morre tanto por seu fim já prefigurado, dado como destino à morte, como alimento para o outro-humano, quanto por sua singularidade que extravasa o limite da compreensão do que se pode nomear, descrever e apreender por parte do ser humano. Ofélia é apenas a metáfora do humano que, não sabendo lidar com a estranheza do animal, submete-o à sua forma, ao seu domínio, como se o animal fosse sua propriedade, como se fosse possível dispor de sua vida, de sua liberdade e de sua existência. Talvez, o que a galinha do conto "Uma galinha" estivesse pronta a anunciar fosse a sua existência enquanto ser existente, enquanto ser que se sabe no mundo, mas que fora subitamente calada pelo homem que lhe segurou brutal 


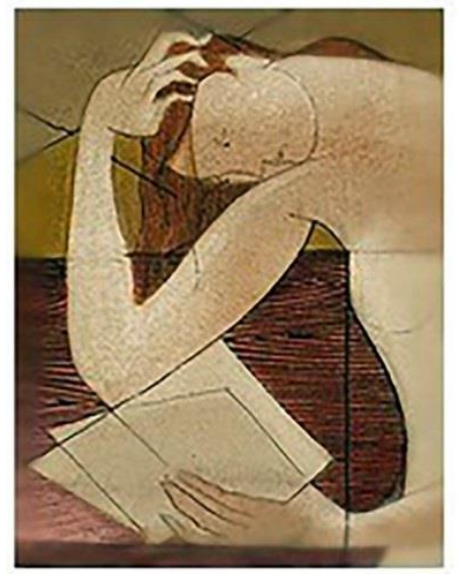

Nau Literária

crítica e teoria da literatura em língua portuguesa

PPG-LET UFRGS

ISSN 1981-4526

$$
\begin{gathered}
\text { https://seer.ufrgs.br/NauLiteraria } \\
\text { V. 17, n.1 - } 2021
\end{gathered}
$$

Dossiê Clarice Lispector: Iluminações para o tempo presente

e covardemente por uma só asa, maltratando-a e eliminando dela toda e qualquer pretensão de se saber ser, igualmente ao cão do conto "O crime do professor de matemática", quando a sua potencialidade de ser é suprimida pelo abandono-crime do professor:

"Há tantas formas de ser culpado e de perder-se para sempre e de se trair e de não se enfrentar. Eu escolhi a de ferir um cão", pensou o homem. "Porque eu sabia que esse seria um crime menor e que ninguém vai para o Inferno por abandonar um cão que confiou num homem. Porque eu sabia que esse crime não era punível."

(LISPECTOR, 2020 a, p. 118)

Agora, para concluir, substituamos a palavra cão, presente na citação acima, pela palavra galinha e ouviremos o acorde uníssono do seu desesperado cacarejar tornando-se inaudível, desesperadamente inaudível.

\section{Referências}

ARÊAS, Vilma. Clarice com a ponta dos dedos. São Paulo: Companhia das Letras, 2005.

BÍBLIA: NOVO TESTAMENTO: OS QUATRO EVANGELHOS. Tradução do grego por Frederico Lourenço. São Paulo: Companhia das Letras, 2017.

DERRIDA, Jacques. O animal que logo sou. Tradução de Fábio Landa. São Paulo: Editora UNESP, 2002.

GOTLIB, Nádia Battella. Clarice: uma vida que se conta. São Paulo: Editora da Universidade de São Paulo, 2013.

LEVINAS, Emmanuel. Le temps et l'autre. Paris: PUF, 2011.

LISPECTOR, Clarice. A vida íntima de Laura. Rio de Janeiro: Rocco Pequenos Leitores, 2012.

LISPECTOR, Clarice. O ovo e a galinha. In: . Todos os contos: Clarice Lispector.

Rio de Janeiro: Rocco, 2016. pp. 303-313. 


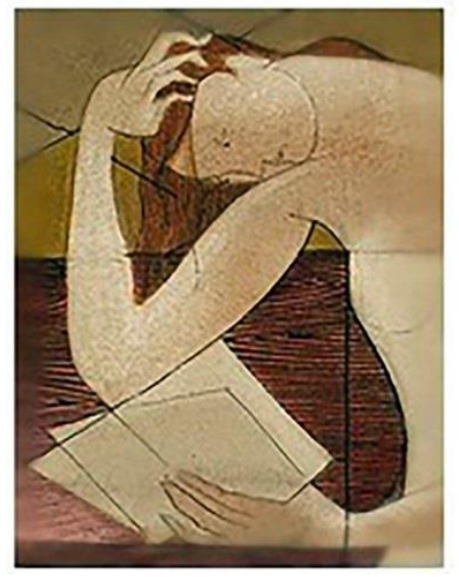

Nau Literária

crítica e teoria da literatura em língua portuguesa

PPG-LET UFRGS

ISSN 1981-4526

$$
\begin{gathered}
\text { https://seer.ufrgs.br/NauLiteraria } \\
\text { V. 17, n.1 - } 2021
\end{gathered}
$$

Dossiê Clarice Lispector: Iluminações para o tempo presente

LISPECTOR, Clarice. A legião estrangeira. In:

Lispector. Rio de Janeiro: Rocco, 2016. pp. 349-365. . Todos os contos: Clarice

LISPECTOR, Clarice. Perto do coração selvagem. Rio de Janeiro: Rocco, 2019.

LISPECTOR, Clarice. A cidade sitiada. Rio de Janeiro: Rocco, 2019 a.

LISPECTOR, Clarice. Um pintinho. In: . A descoberta do mundo. Rio de Janeiro: Rocco, 2020. p. 89.

LISPECTOR, Clarice. Uma história de tanto amor. In: . A descoberta do mundo. Rio de Janeiro: Rocco, 2020. pp. 154-157.

LISPECTOR, Clarice. Bichos (I). In: A descoberta do mundo. Rio de Janeiro: Rocco, 2020. pp. 427-430.

LISPECTOR, Clarice. Bichos (Conclusão). In: A descoberta do mundo. Rio de Janeiro: Rocco, 2020. pp. 431-434.

LISPECTOR, Clarice. Já andei de camelo, a esfinge, a dança do ventre (Conclusão). In: A descoberta do mundo. Rio de Janeiro: Rocco, 2020. pp. 452-453.

LISPECTOR, Clarice. Sou uma pergunta. In: Janeiro: Rocco, 2020. pp. 474-477. A descoberta do mundo. Rio de

LISPECTOR, Clarice. Amor. In: . Laços de família. Rio de Janeiro: Rocco, 2020 a. pp. 17-27.

LISPECTOR, Clarice. Uma galinha. In: Laços de família. Rio de Janeiro: Rocco, 2020 a. pp. 28-31.

LISPECTOR, Clarice. A imitação da rosa. In: Laços de família. Rio de Janeiro: Rocco, 2020 a. pp. 32-50.

LISPECTOR, Clarice. O crime do professor de matemática. In: Laços de família. Rio de Janeiro: Rocco, 2020 a. pp. 112-119.

LISPECTOR, Clarice. A hora da estrela. Rio de Janeiro: Rocco, 2020 b. 


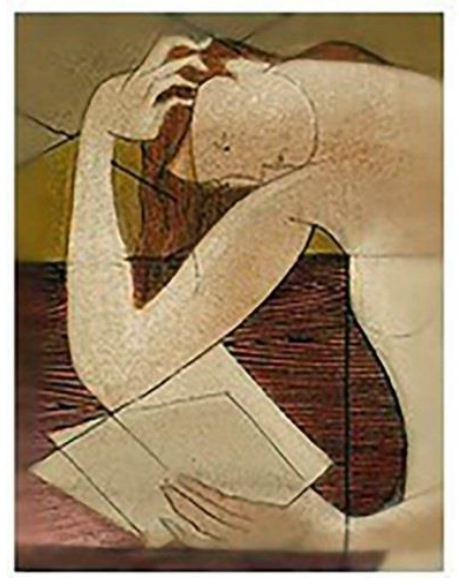

Nau Literária

crítica e teoria da literatura em língua portuguesa PPG-LET UFRGS ISSN 1981-4526

https://seer.ufrgs.br/NauLiteraria V. 17, n.1 - 2021

Dossiê Clarice Lispector: Iluminações para o tempo presente

PLATH, Sylvia. A redoma de vidro. Tradução de Chico Mattoso. Rio de Janeiro: Biblioteca Azul, 2019. 